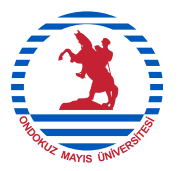

Ondokuz Mayıs Üniversitesi İnsan Bilimleri Dergisi, Ondokuz Mayıs University Journal of Humanities

e-ISSN: 2717-8072, IBDD, December 2021, 2(2): 253-282

\title{
Buket Uzuner'in Kumral Ada Mavi Tuna Adlı Romanında Yer Alan Ana Karakterlerin Toplumsal Cinsiyet Kalıp Yargıları Açısından İncelenmesi
}

\author{
An Investigation of the Main Characters in Buket \\ Uzuner's Novel titled Kumral Ada Mavi Tuna in Terms \\ of Gender Stereotypes
}

\author{
Yüksek Lisans Öğr. Fatma DEMIR'', Doç. Dr. Zerrin EREN² \\ 1 Ondokuz Mayıs Üniversitesi Lisansüstü Eğitim Enstitüsü \\ - fatma.yolcu.86@hotmail.com • ORCID > 0000-0003-0755-9862 \\ 2 Ondokuz Mayıs Üniversitesi Eğitim Fakültesi \\ •erenz@omu.edu.tr•ORCID > 0000-0002-8579-6639 \\ Makale Bilgisi / Article Information \\ Makale Türü / Article Types: Araştırma Makalesi / Research Article \\ Geliş Tarihi / Received: 9 Kasım / November 2021 \\ Kabul Tarihi / Accepted: 8 Aralık / December 2021 \\ YIl/Year: 2021 | Cilt -Volume: 2 | Sayı-Issue: 2 | Sayfa / Pages: 253-282
}

Atıf/Cite as: Demir, F. ve Eren, Z., "Buket Uzuner'in Kumral Ada Mavi Tuna Adlı Romanında Yer Alan Ana Karakterlerin Toplumsal Cinsiyet Kalıp Yargıları Açısından Incelenmesi - An Investigation of the Main Characters in Buket Uzuner's Novel titled Kumral Ada Mavi Tuna in Terms of Gender Stereotypes", Ondokuz Mayıs Üniversitesi Insan Bilimleri Dergisi- Ondokuz Mayıs University Journal of Humanities, 2 (2), Aralık 2021: 253-282.

https://10.51533/insanbilimleri.1021434 


\section{BUKET UZUNER'IN KUMRAL ADA MAVI TUNA ADLI ROMANINDA YER ALAN ANA KARAKTERLERIN TOPLUMSAL CINSIYYT KALIP YARGILARI AÇISINDAN INNCELENMESI}

\section{AN INVESTIGATION OF THE MAIN CHARACTERS IN BUKET UZUNER'S NOVEL TITLED KUMRAL ADA MAVI TUNA IN TERMS OF GENDER STEREOTYPES}

ÖZ:

$\mathrm{Bu}$ çalışmanın amacı Buket Uzuner'in Kumral Ada Mavi Tuna adlı eserinde toplumsal cinsiyetin bireye ne şekilde sunulduğu, romanda yer alan olay ve ana karakterlerin toplumsal cinsiyet kalıp yargılarını destekler nitelikte olup olmadığı, kadın erkek-eşitsizliğine romanda yer verilip verilmediğini incelemektir. Romanın ana karakterleri, toplumsal cinsiyet kalıp yargı ve rolleri bağlamında ele alınmış, romanda kadın-erkek eşitsizliğinin giderilmesine katkı sağlayan ifadelere yer verilip verilmediği tartışılmıştır. Uzuner'in Kumral Ada Mavi Tuna eserinin, toplumda var olan kadın erkek eşitsizliğinin giderilebilmesine, bu konuda farkındalık kazanılmasına katkı sağlayabilecek bir eser olduğu sonucuna ulaşılmıştır.

Anahtar Kelimler: Toplumsal Cinsiyet Rolleri, Kadinsillk ve Erkeksilik, Buket Uzuner, Kumral Ada Mavi Tuna.

\section{ABSTRACT:}

The aim of this study is to examine how the gender is presented to the reader, whether the events and main characters in the novel support dominant gender stereotypes, in society, whether there is gender inequality in Buket Uzuner's work titled Kumral Ada Mavi Tuna. The main characters in this study have been discussed in the context of gender roles and stereotypes; the novel has been scrunitized to find out whether there are expressions contributing to the reduction of gender inequality in the novel. It has been concluded that Uzuner's Kumral Ada Mavi Tuna is a work that can contribute to the reduction of inequality between women and men in society and to raise awareness on this issue.

Key Words: Gender Roles, Femininity and Masculinity, Buket Uzuner, Kumral Ada Mavi Tuna. 


\section{GíRiş}

21. yüzyılda, hızla küreselleşen, sürekli gelişen bir dünyadan bahsetmek mümkündür. Değișen tüm dünya dengelerine rağmen günümüz dünyasında, kadın erkek eşitsizliğinin halen var olduğu, bu eşitsizliğin kadınların aleyhine olmaktan çıkamadığı aşikârdır. Yüzyıllardır ataerkil sistemin öğretilerinin içselleştirilmiş olması bu eşitsizliğin giderilememesinde belki de en büyük nedendir. İnsanlık tarihi kadar eskiye dayanan bu düzen, nesilden nesile, sözlü ve yazılı anlatımla bireylere ulaşmış ve ulaşmaya devam etmektedir.

Kadın ve erkeğin yaşadıkları toplumda "kadınlık ve erkeklik" rollerinin ne şekilde kabul edildiği, bireylere yüklenen bu rollerin neler olduğu, bu rollerin kadın ve erkeklerin cinsel kimlik kazanımını ne şekilde etkilediği merak konusu olmuş ve birçok çalışmada bu sorulara yer verilmiştir. Cinsiyet ve toplumsal cinsiyet kavramları bu çalışmaların en önemli iki kavramı olarak karşımıza çıkmaktadır.

Cinsiyet, canlıların cinsiyet kromozomları tarafından belirlenen yapısal, işlevsel ve davranışsal özelliklerini içerir. ${ }^{[1]}$ Başka bir ifadeyle cinsiyet kişinin fiziksel, biyolojik ve genetik özelliklerini ifade eder. Bu özellikleri birey doğuştan getirir. Diğer taraftan bireyin içerisinde var olduğu toplum, doğumundan başlayarak bireyi biyolojik cinsiyetine göre birtakım değer ve yargılarla kuşatmaya başlar. $\mathrm{Bu}$ değer ve yargılar toplumun geneli tarafından benimsenen ve bireyin biyolojik cinsiyetine dayanarak bireylerde olduğu varsayılan kişilik özellikleri ya da bireylerde yapmaları beklenilen rollerin tümünü kapsar. O halde toplumsal cinsiyet, toplumun bireye verdiği roller, görev ve sorumluluklar, toplumun bireyi nasıl gördüğü, algıladığ 1 , beklentileri ile ilgili bir kavramdır. ${ }^{[2]}$

Toplumsal cinsiyet, kültürel olarak belirlenir. Dünyanın bütün toplumlarında doğuştan gelen biyolojik farklılıklar kültürel olarak yorumlanıp değerlendirilir. Böylece kadın ve erkeğin hangi davranış ve faaliyetleri yapabileceklerine, hangi haklara ve güce kimin ne derece sahip olduğuna veya sahip olması gerektiğine dair toplumsal beklentiler geliştirilir. Bu beklentilerin, toplumdan topluma veya aynı toplum içinde bir kesimden diğerine kısmen değişse de özünde ortak noktaları vardır. Bu ortak noktaların (benzerliklerin) nedeni, dünya üzerindeki toplumların çok büyük bir kısmında ataerkil sistemin varlığ 1 olabilir. Hem özel alanda hem de kamusal alanda erkeğin kadın üzerindeki hâkimiyetine işaret eden ataerkillik kavramı, çoğunlukla erkek ile kadın arasındaki güç ilişkisini tanımlamak amacıyla kullanılır; bu kavram, genelde toplumda kadın üzerindeki erkek egemenliğini arttırma, ailede çocuk ve kadın üzerinde erkek egemenliğinin kurumsallaşması

1 Britta N. Tongrimson ve Christopher Minson, "Sex and Gender: what is the difference?", Journal of Applied Physiology, 99, 2005, s. 785-787.

2 Britta N. Tongrimson ve Christopher Minson, "Sex and Gender: what is the difference?", s. 785-787. 
ve gösterimini ifade eder. ${ }^{[3]}$ Öyleyse toplumsal cinsiyetin bireyler tarafından neredeyse bilinçsiz şekilde öğrenilmesinde en önemli neden olarak ataerkillik ifade edilebilir.

Bireyler, toplumda sahip oldukları rollerini yerine getirirken aslında toplumsal yapının onlara atfettiği rollere göre davranırlar. ${ }^{[4]}$ Rol, çeşitli çalışmalarda belli bir toplumsal duruma ilişkin olarak beklenen davranışlar, davranış kalıpları, gerçek ya da beklenen edimlerin toplami ${ }^{[5]}$ olarak ifade edilmiştir. Bu bağlamda rol, toplumsallığın bireyde davranışa dönüşmesidir. Toplumsal cinsiyet rolleri bireyin er ya da dişi olarak, bulunduğu toplumda yaşamın değişik kademelerinde yapmaları gereken iş ve sorumlulukları belirler. ${ }^{[6]}$ Bir başka deyişle, toplumsal cinsiyet rolleri, her toplumun kendi kültürel içeriğinde yer alan kadınlık ve erkeklik kavramlarına uygun olarak, kadınlardan ve erkeklerden beklediği kişilik özellikleri, giyim tarzı, tutum ve davranışlardır. ${ }^{[7]}$ Kadın ve erkeklerden, toplumun beklentileri ile biçimlenen bu rollere, tutum ve davranışlara sadık kalmaları beklenmektedir. $\mathrm{Bu}$ beklentiler farklı toplumlarda farklı ya da benzer özellikler gösterebilir. ${ }^{\left[{ }^{8]}\right.}$ Atay Çin Isşi, Japon İşi adlı kitabında erkeklik ve kadınlığın doğal haller olmadığını, kültürel pratikler olduğunu ifade eder. ${ }^{[9]}$ Atay, buna örnek olarak 1930'larda Mead'ın Okyanusya yerlileri üzerindeki bir çalışmasından bahseder. Çalışmada yer alan, Arapesh toplumunda hem kadınların hem erkeklerin modern batıda beklenen tavır ve davranışları sergilediği, yumuşak, hassas, başkalarının istek ve taleplerine duyarlı, saldırganlıktan uzak olduğu görülür. İkinci topluluk olan Mundugumor'da kadınlar ve erkeklerin Batı dünyasında erkeklerden beklenen davranışları sergilediği görülür: Şedit, saldırgan, sert... Diğer topluluk Tchambuli’de ise Batı’da beklenilenin tam tersine, erkeklerin uysal, yumuşak olup, alışveriş yaptıkları, evin ihtiyaçları ve çocuk bakımıyla ilgilendikleri, kadınların ise sert, dominant ve yönetici tavır sergiledikleri görülür. ${ }^{[10]}$ Mead'in çalışması, bu çalışmaya kadar ataerkil toplumlarda biyolojik olduğu düşünülen kadınsı ve erkeksi özelliklerin, kadınsı ve erkeksi rollerin, biyolojik değil, kültürel olduğunu göstermesi bakımından önemlidir.

3 Abeda Sultana, “Ataerkillik ve Kadının İkincilliği; Kuramsal Bir Analiz”, e-Şarkiyat ilımi Araştırmalar Dergisi, 11/1, Nisan 2019, s. 418.

4 Gordon Marshall, Sosyoloji Sözlüğü, Osman Akınhay-Derya Kömürcü (çev.). Bilim ve Sanat Yayınları, Ankaга 1999, s. 624.

5 Mine Tan, Ekonomik Yaşamı ve Eğitimi, Türkiye Iş Bankası Yayınları, Ankara 1979, s. 158.

6 Selmin Evrim, Şahsiyet Alanında Psikososyolojik Bir Kavram Olarak Rol Sorununa Giriş, İstanbul Üniversitesi Edebiyat Fakültesi Yayınları, İstanbul 1972, s. 102.

7 Zerrin Eren, Baba Karnım Acıktı Anne Bisikletim Bozuldu, Favori Yayınları, Ankara 2015, s. 20.

8 Zehra Yaşın Dökmen, Toplumsal Cinsiyet Sosyal Psikolojik Açıklamalar, Remzi Kitabevi, İstanbul 2004, s. 24.

9 Tayfun Atay, Çin Işi, Japon Işi, İletişim Yayınları, İstanbul 2017, s. 31.

10 Tayfun Atay, Çin Işsi, Japon Işsi, s. 31. 
Tarih boyunca kadınlar, erkeklerden daha düşük statüde kalmış, erkeklere göre daha az hak ve şansa sahip olmuş, birçok yönden eşitsizliğe mahkûm bırakılmışlardır. ${ }^{[11]}$ Toplumsal cinsiyet alanında yapılan çalışmalarda bu eşitsizlik durumlarının; haklarda eşitsizlik, kaynaklarda eşitsizlik, ekonomik faaliyet alanında eşitsizlik, kamusal ve siyasal alanda eşitsizlik, sağlık hizmetlerine erişebilme açısından eşitsizlik gibi gruplara ayrılarak açıklanmaya çalışıldığ̣ görülür. ${ }^{[12]} \mathrm{Bu}$ eşitsizliklerin temeline baktığımızda, ataerkil sistemin hâkim olduğu toplumlarda kadının, erkek egemenliğine boyun eğmek zorunda kaldığını söylemek mümkündür. Erkeğin hâkim gücünün, kendini her alanda gösterdiği, kadını ise daima ikincil konumda bıraktığı ifade edilebilir.

Toplumsal cinsiyet rollerinin oluşmasında ve değişiminde; aile, okul, din kurumları, medya gibi oluşumlar etkilidir. ${ }^{[13]}$ Bunun yanı sıra sözlü ve yazılı edebiyat ya da sanat dallarının da önemi yadsınamaz. Toplumsal cinsiyet kavramı, zaman içinde değişebilen dinamik bir kavramdır. ${ }^{[14]} \mathrm{Bu}$ değişime katkı sağlayan pek çok değişken vardır. Toplumdaki yeri ve konumu bebeklikten itibaren şekillendirilen bireyin, cinsiyetinden beklenen tavır ve davranışları öğrenmesine hiç şüphesiz kitaplar da katkı sağlamaktadır. Bu nedenle kitapların verdiği iletilerin önemi büyüktür. Toplumda var olan eşitsizliğin giderilebilmesinin ancak bu konuda oluşacak farkındalık ile mümkün olduğu düşünülmektedir. Bu amaçla Buket Uzuner’in Kumral Ada Mavi Tuna adlı eserinde toplumsal cinsiyet kavramının bireye ne şekilde sunulduğu, romanda yer alan olay ve karakterlerin toplumsal cinsiyet kalıp yargılarını destekler nitelikte olup olmadığı, kadın erkek-eşitsizliğinin romanda yer alıp almadığı, karakterlerin kadınsılık ve erkeksilik özellikleri sergileyip sergilemedikleri incelenecektir. Bu çalışmada yer alan karakterler, toplumsal cinsiyet algısı bağlamında ele alınacak, romanda kadın-erkek eşitsizliğinin giderilmesine katkı sağlayan ifadelere yer verilip verilmediği ortaya çıkarılacaktır. Bu çalışma, romanın ana karakterleri olan Ada, Tuna ve Aras'ın özellikleriyle sınırlıdır. Romandaki ana karakterlerin kişilik özellikleri toplumsal cinsiyet kalıp yargıları ve toplumsal cinsiyet rolleri ile ilgili kuramlarla karşılaştırılacak, ana karakterlerin kişilik özelliklerinin kuramlarla uyumlu olup olmadıkları değerlendirilecektir.

$\mathrm{Bu}$ çalışma ile toplumsal cinsiyet kalıp yargıları ve toplumsal cinsiyet rolleri ele alınarak, başta bu konular ile ilgilenenler olmak üzere sosyal bilimlere, feminist edebiyat eleştirisine ve kadın çalışmaları alanlarına katkı sağlaması amaçlanmıştır.

11 Sevda Demirbilek, "Cinsiyet Ayrımcılı̆ının Sosyolojik Açıdan İncelenmesi”, Finans, Politik,Ekonomik Yorumlar, 44/511, 2007, s. 25.

12 Anahit Coşkun ve Resmiye Özdilek, "Toplumsal Cinsiyet Eşitsizliği: Sağlığa Yansıması ve Kadın Sağlığı Hemşiresinin Rolü”, Hemşirelikte Eğitim ve Araştırma Dergisi, 9/3, 2012, s. 48.

13 James William ve Harold R. Kerbo, Social Problems: A Brief Introduction, Second Edition, Prentice Hall, New Jersey 2003, s. 277.

14 Zehra Yaşın Dökmen, Toplumsal Cinsiyet Sosyal Psikolojik Açıklamalar, Remzi Kitabevi, İstanbul 2004, s. 24. 


\section{Ada}

Romanın ana karakteri Tuna ailesiyle birlikte Kuzguncuk'ta yaşamaktadır. Romanın diğer ana karakteri olan Ada’nın ailesi, Tuna’nın yaşadığ 1 evin yakınında olan bir köşke taşınırlar ve komşu olurlar. Ada, Tuna’nın küçük yaşlardan beri saplantılı bir şekilde âşık olduğu, her tavrına, her hareketine, her haline hayran kaldığı, âdeta kendi ruh dünyasında yeniden yarattığı bir karakterdir. Ada’yı ilk gördüğü andan itibaren nasıl etkilendiğini Tuna, “Tam anlamıyla büyülenmiştim. Hani anlatmak için sözcüklerin yetersiz kaldığı, ancak mecazlarla, metaforlarla ifade edilebilecek insanlardandı $\mathrm{o}^{\text {"[15] }}$ şeklinde ifade eder.

Tuna, Ada'yı alımlı, kişilikli ve kumral bir kadın olarak tanıtmaktadır. Tuna sık sık Ada’nın güzelliğini anlatacak cümle bulmakta zorlandığını ifade eder:

Onu anlatmak için güzel, boylu poslu, sarışın/esmer, şahane gibi sözcükler haksızlık olurdu. Onun için bu dünya dışından gelmiş kadar değişik, bir kuyruklu yıldız kadar etkileyici, iyi pişmiş kahve kadar tiryakilik yaratıcı, gezegene yalnız yollandığg için eşsiz... Dingin ve içe sinmiş bir güzellikti onunkisi. ${ }^{[16]}$

Toplumsal cinsiyet rolleri kadınlara duygusal, ikincil ve pasif olma rolleri ile, aklını kullanmasının yerine güzel ve albenili olmasını bekleyen dayatmalar da sunar. ${ }^{[17]}$ Güzel beden kavramı pek çok dönemde, kadınla bağdaştırılmış ve kadın imgeleriyle örneklenmiştir. ${ }^{[18]}$ Kadının boyu, kilosu, ten rengi, göz rengi, yüz hatları gibi özellikleri ile güzellik algısı arasında doğrudan bağ kurulmuştur. Kadının güzelliği nice şiire, sayısız türküye konu olmuştur. Birçok sanat eserinde güzel kadın imgesi yer almıştır. Bu bağlamda 'güzellik' kadınsı özelliklerden sayılmıştır. Tuna’nın gözüyle tanıyabildiğimiz Ada karakterinde güzellik, etkileyicilik, zariflik gibi sıfatların bulunduğu anlaşılır. Nitekim romanda, Tuna sık sık Ada’nın güzelliğini, zarifliğini dile getirir. “...Ada Mercan! Mahallenin bal prensesi, akılll, zarif, görgülü kızı..." [19] Zarif, kelimesi "hoşluk, çekicilik, incelik”"[20] anlamlarına gelir. Zarafet (zariflik), toplumda kabul gören kadınsı özelliklerden biridir. Zarif olan bir kadın, toplumda olumlu karşılanır. Kız çocuklarının zarif bir şekilde yetiştirilmesi önem arz eder. Ada’nın da bu bağlamda kadınsı bir özellik olan zarifliği taşıdı̆̆ı

15 Buket Uzuner, Kumral Ada Mavi Tuna, Everest Yayınları, İstanbul 2015, s. 19.

16 Buket Uzuner, Kumral Ada Mavi Tuna, Everest Yayınları, İstanbul 2015, s. 19.

17 Yonca Altındal, “Kadınları Tepeden Tırnağa Boyayan Kadınlar: Güzellik Salonlarında Çalışan Kadınların İş, Yaşam ve Aile Döngüleri Yaşam ve Aile Döngüleri", Marmara Üniversitesi Kadın ve Toplumsal Cinsiyet Araştırmaları Dergisi, 1/1, 2017, s. 65.

18 Hale Çevlik, Güzel Olarak Nitelendirilen Kadın Imgesinin Yorumlanması, (Yayımlanmamış Yüksek Lisans Tezi) , Süleyman Demirel Üniversitesi Güzel Sanatlar Enstitüsü Resim Anasanat Dalı, Isparta 2012.

19 Buket Uzuner, Kumral Ada Mavi Tuna, s. 119.

20 TDK Sözlük, Ülke Yayınları, İstanbul 1982, s. 1342. 
görülür.

Tuna’ya göre Ada, güzel, zarif olmasının yanı sıra, son derece dişi ve çekici bir kizdir.

Oysa gözlerinden zeki pırıltılar, dudaklarından yaramaz gülücükler saçarak ve açıcça meydan okuyarak yürek hoplatan Ada son derece seksiydi. Kıvılcım da söz mü, Ada etkilediği erkeği tehlikeli şimşeklerle, gökkuşağı arasında sürekli teyakkuzda tutabilen tutkusal dişilerdendi. ${ }^{[21]}$

Tuna’nın gözüyle tanıyabildiğimiz Ada karakterinin kadınsı özelliklerden sayılan güzel, "kırılgan, alımlı”[22], narin, dişi ve çekici olmak gibi özellikleri taşıdığı görülür. Ada’nın bu yönleriyle kadınsı özellikler taşıdığını söylemek uygun olacaktır.

Romanımızın ana karakterlerinden Ada’nın, bahsettiğimiz kadınsı özelliklerin yanı sıra erkeksi özellikler olarak kabul edilen özelliklere de sahip olduğunu ifade etmek gerekir. Toplum tarafından kadınların ve erkeklerin sahip oldukları düşünülen kişilik özellikleri genel olarak kadınsı (feminen) ve erkeksi (maskülen) özellikler olarak nitelendirilmektedir. Kadınlardan toplum tarafından kabul gören kadınsı özelliklere sahip olup, erkeksi özellikleri taşımamaları; erkeklerden ise erkeksi özelliklere sahip olup kadınsı özellikler göstermemeleri beklenmektedir. ${ }^{[23]}$ Ada, Tuna’nın ailesi tarafından da sevilen bir kızdır, ancak onların bildiği 'sıradan' kızlardan farklıdır. İlkokula giderken üst üste sınıf başkanlığına seçilen, mahallenin en popüler çocuğu olan Aras’a rakip olur ve sınıf başkanı seçilir. Bu duruma içerleyen Aras'la ertesi sene aralarında kıyasıya bir rekabet yaşanır. Ada kendine güvenen, kararlı bir kızdır. Bu yarışı kazanabilmek için vaat vermekten çekinmez: "Beni seçerseniz" diyordu Ada, "beni seçerseniz ayda bir kez herkese bir masal kitabı armağan ederim, doğum günlerinizde ailenizle fotoğraf çektirir, gofret ve kola ikram ederim" [24] Ada'nın Aras'la rekabet etmesi, onda var olan erkeksi özelliklere bir örnektir. Çalışmalarda rekabetçilik özelliği erkeksi özelliklerden biri olarak karşımıza çıkar. ${ }^{[25]}$ Sınıf başkanı olmak istemesi ve seçilmesi ise sınıfta lider bir öğrenci olduğu anlamına gelir. Liderlik de erkeksi özelliklerden biridir. ${ }^{[26]}$ Ada bu anlamıla da erkeksi bir özelliğe sahiptir.

21 Buket Uzuner, Kumral Ada Mavi Tuna, s. 290.

22 Buket Uzuner, Kumral Ada Mavi Tuna, s. 4.

23 Betül Aydın ve Ayşe Nur Kavuncu, "Farklı Sosyo-Ekonomik Düzeylerdeki Lise Öğrencilerinde Cinsiyet Rollerinin Araştırılması", Psikolojik Danışma ve Rehberlik Dergisi, 1/2, 1991, s. 23.

24 Buket Uzuner, Kumral Ada Mavi Tuna, s. 119.

25 Celaleddin Vatandaş, "Toplumsal Cinsiyet ve Cinsiyet Rollerinin Algılanışı", Sosyoloji Konferansları, 35, 2011, s. 47.

26 Zehra Yaşın Dökmen, "Bem Cinsiyet Rolü Envanteri Kadınsılık ve Erkeksilik Ölçekleri Türkçe Formunun Psikometrik Özellikleri”, Kriz, 44/511, 1999, s. 30. 
Ayrıca Tunảnın dedesinin Ada ile ilgili aşağıdaki sözleri dikkat çekicidir:

Bu kızanı erkek gibi yetiştirmişler bre!. Çok konuşur soru sorar, gözünü budaktan esirgemez kerata! Hah, hah, hah! Aslında severim yaramazı, çok güvenir kendine. Toprağı bol olsun, Rozita'yı atırlatır bana cevvalliği...fakat kız dediğin anım anımcık olmalı az birazcık kizanlar! [27]

Tuna’nın dedesinin cümlelerinden, Ada’nın bir kızdan beklenilmeyen özellikleri olduğu anlaşılır. Ada’nın kendine güvenen, cevval bir kız olması erkeğe benzetilir. Bu özelliklerin ancak bir erkekte bulunduğunda 'normal' olduğu düşünülür. Ada’nın kafasına koyduğunu yapan, tuttuğunu koparan, kararlı ve başarılı oluşu erkeksi özellikler arasında yer aldığından Tuna’nın dedesi tarafından eleştirilir. Diğer taraftan dedenin cümlelerinden Ada'yı sevdiği anlaşılır. Toplumda da erkeksi özellikler taşıyan kadınların olumlu karşılandığı bilinmektedir. 'Erkek gibi kadın' tabiri sık duyduğumuz bir tabirdir ve toplum nazarında olumlu karşılanır. Kendine güvenen, ayakları üzerinde durabilen kadınlar için kullanılan bu ifadelerden, kadının erkeğe benzediği için yüceltildiği algısı çıkar. Oysa tam tersi bir algının, yani erkeğin kadına benzemesi durumunun aşağılayıcı bir durum olarak görülmesi ve hakaret sayılması toplumsal cinsiyetin kadını ikincilleştirdiğinin bir göstergesidir.

Ada, çocukluğunda rekabet içerisinde olduğu arkadaşı Aras ile tutkulu bir aşk yaşar. Aras, Tuna’nın öz ağabeyidir ve ikisi arasında yaşanan aşkın en yakın şahididir. Ada bu ilişkide de kendine güvenen bir duruş sergiler. Çok yakışıklı ve dikkat çeken bir genç olan Aras'ı sahiplendiğini etrafına göstermekten çekinmez: "Ada kendi kupundan bir kaşık alarak Aras’ın ağzına uzattı"[28] ifadeleri Ada’nın topluluk içinde çekingen tavırları olmadığını gösterir. Daha sonra Tuna’nın "Sonra yüzünde çapkın bir gülücükle uzanıp Aras’n yanağını okşadı. Hâlâ Aras’a gözlerini dikmiş öbür masa kızlarına bir ihtar olmalıydı bu" ${ }^{\text {[29] }}$ cümlelerinden Ada’nın Aras’ı sahiplendiğini anlamak mümkündür. Ada’nın, sevdiğini sahiplendiğini gösterebilen ve bunu etrafına göstermekten çekinmeyen bir kız olduğu anlaşılmaktadır. Çoğu zaman erkeklerde görülen bu özellikler, Ada’nın sahip olduğu erkeksi özelliklerden sayılabilir.

Ada, Aras'la birlikte Amerika'da eğitim görmek ister. Aras'ın ise farklı planları vardır ve Amerika’ya gitmek istemez. Ada âşık olduğu erkeğin gölgesinde kalacak bir kız değildir. "O zaman Amerika'ya ben yalnız giderim, dedi Ada kırgın ama kafa tutan bir sesle" ${ }^{[30]} \mathrm{Bu}$ ifadelerden, Ada’nın kendi bildiğinden şaşmayan bir kız

\footnotetext{
27 Buket Uzuner, Kumral Ada Mavi Tuna, s. 110.

28 Buket Uzuner, Kumral Ada Mavi Tuna, s. 217.

29 Buket Uzuner, Kumral Ada Mavi Tuna, s. 218.

30 Buket Uzuner, Kumral Ada Mavi Tuna, s. 220.
} 
olduğu çıkarımını yapmak mümkündür. Toplumsal cinsiyet kalıp yargılarına göre, genellikle kadınların pasif olması gerektiği düşünülür. ${ }^{[31]}$ Ada, kadınsılık özelliklerinden kabul edilen pasif olmak özelliğini taşımaz.

Sevgilisi Aras’ın, talihsiz bir şekilde ölümünden sonra Ada şoka girer, günlerce hastanede kalır. Hastaneden çıktıktan sonra okulu bırakmaya karar verir. Annesi ile yurt dışına gider. Orada kendi isteği ile fotoğrafçılık kursuna gider ve kendini geliştirir. Fotoğrafçılık konusunda gayet yeteneklidir. Yurt dışında başarılı bir fotoğrafçı olarak tanınmaya başlar. Tuna, Ada’nın bu durumunu aşağıdaki ifadelerle anlatır:

Ada sonraki dört yılı yine Kuzey Amerika'da geçirdi. Bir lise, bir de sanat koleji diploması aldı, ama en önemlisi Ada bir fotoğraf sanatçısı olarak kendini Amerika'nın kuzeyinde kabul ettirmeye başladı. Sarı, turuncu ve kırmızı sonbahar ve beyaz kış fotoğraflarını kartpostal olarak bastırıp yerel kitabevlerinde sattırmayı başardı. Son iki yıl artık ailesinden yardım almadan yaşamını kazandığını gururla yazdı bana. ${ }^{[32]}$

Bu tartışmadan da anlaşılacağı üzere, Ada yaşadığı zor günlere rağmen kendi kararlarını alabilen, kendi ayakları üzerinde durabilen, başarılı bir kız olabilmiştir. Çalışmalarda güçlü kişilik özelliği, kolay karar verebilme, kendi kendine yetebilme gibi özelliklerin erkeksi özellikler olduğu görülür. ${ }^{[33]}$ Ada’nın, erkeksi özellikler olarak karşımıza çıkan; güçlü, kendi kendine yeten, kolayca karar verebilen, başarılı olmak gibi sıfatları taşıdığını söylemek mümkündür. Türkiye’ye döndükten sonra kendisine ayrı bir ev kiralayan Ada, kolay pes etmeyen bir kişilik yapısına sahiptir. $\mathrm{Bu}$ anlamda da erkeksi özellikler taşıdığını söylemek yerinde olacaktır.

Yurt dişından döndükten sonra Ada kendisi gibi fotoğrafçılıkla uğraşan, Aliye adında bir arkadaş edinir. Aliye çocukluğunda istismara uğramış, sabıkası olan, davranışlarıyla dünyadaki tüm insanlardan intikam almaya çalışan bir kız olarak tanıtılır. Ada’nın sarhoş olduğu bir gün Ada'dan cinsel olarak faydalanmaya çalışır. Ada ise o anda tam kendinde olmamasına rağmen bu sevişmeden haz aldığını saklamaz. Ada’nın doğum gününe davetsiz olarak gelen Aliye, orada Ada'yla sevgili olduklarını söyler ve ortam gerilir. Orada bulunanlar Ada’nın lezbiyen olması ihtimali ile şaşkınlık geçirir: "Hakkımda tıpkı o dehşet gecesi Aras’ı benim denize itip öldürdüğüme dair olduğu gibi, şimdi de eşcinsel, lezbiyen olduğum dedikoduları

31 Zehra Yaşın Dökmen, Toplumsal Cinsiyet Sosyal Psikolojik Açıklamalar, Remzi Kitabevi, İstanbul, 2009, s. 32.

32 Buket Uzuner, Kumral Ada Mavi Tuna, s. 110.

33 Ayşe Nur Kavuncu, Bem Cinsiyet Rolü Envanteri'ni Türk Toplumuna Uyarlama Çalışmaları, (Yayımlanmamış Yüksek Lisans Tezi), Hacettepe Üniversitesi Sosyal Bilimler Enstitüsü Eğitim Bilimleri Anabilim Dalı, Ankara 1987, s. 55. 
çıkmış. Çıksın! Ne yapayım? Lezbiyen olsaydım bunu saklamazdım, bilirler beni. "[34]

Ada'nın kendisiyle ilgili bu ifadeleri cinsel tercihi toplumun beklentilerine uymuyor olsaydı bile bunu çekinmeden söyleyebileceğinin bir göstergesidir. Toplumsal cinsiyet kalıp yargıları, kadın ve erkeğin cinsel tercihlerini ancak heteroseksüel olduğunda normal karşılar. Bunun dışında lezbiyenlik, homoseksüellik gibi cinsel tercihleri olan insanları ikincil konumda bırakır. Hatta toplumda bu tercihlerle yaşayan kadın ve erkekler dışlanma ile karşı karşıya kalırlar. Cinsel tercihleri kalıp yargilarla uyumlu olmayan bireyler, çoğu zaman da toplumda bu yönleriyle görünür olmaktan çekinirler. Ada karakterinin yukarıda yer alan ifadelerinden, toplumun bu çifte standartlı yaklaşımına kafa tutacak kadar özgüvenli olduğu anlaşılır. Ada’nın toplumun bu dayatmalarına karşı bir duruşu olan bir karakter olduğu görülür. Toplumsal cinsiyet kalıp yargıları incelendiğinde erkeksi özelliklerin atılgan, korkusuz, akılcı, güvenli, bağımsız, soğukkanlı, güçlü, aktif gibi sıfatlarla tanımlandığ1 görülür. ${ }^{[35]}$ Öyleyse Ada’nın özgüvenli, çekinmeden düşündüğünü ifade eden cesur kişiliği erkeksi özellikleri arasında yer alır.

Kadınlara ve erkeklere atfedilen toplumsal cinsiyet kalıp yargıları kadınsı özelliklerin sevecen, duygusal, hassas, 1lımlı, bağımlı, şefkatli, boyun eğen mütevazı, narin, hasta ve çocuklara bakım veren, pasif gibi sıfatlarla tanımlandığını gösterir. ${ }^{[36]}$ Romanda Ada ve Tuna arasında sıcak ve samimi bir arkadaşlık ilişkisinden bahseder. Tuna, Ada’ya karşılıksız bir aşk yaşasa da Ada’nın Tuna’ya olan bağlılığı ve sevgisi de açıkça hissedilir. Ada Tuna’yla olan arkadaşlık ilişkisinde daima şefkat doludur. "Birlikte oynarken bana bir arkadaştan çok, onun küçük bebeğiymişim gibi davranıyor, oyunlarda annem oluyordu"[37] ifadeleri Ada’nın şefkatinin küçük yaşlardan beri var olduğunu gösterir. Ada, Tuna'yı kuzeni Meriç’ten dahi korumaya çalışır: "Ada beni daha önce hiç azarlamamıştı. Meriç’i çekiştirerek banyodan çıkartırken azarlıyordu hâlâ: O daha çocuk, sakın elini sürme ona"[38] cümleleri Ada’nın Tuna’ya duyduğu şefkatin bir başka göstergesidir. Öyle ki Ada, Tuna’ya zarar veririm endișesi ile yıllarca Tuna'dan uzak durur. Üstelik Tuna’nın ona ne kadar âşık olduğunu bilmektedir. Tuna’nın incinmesini asla istemez. Ada, Tuna’ya duyduğu sevgiyi şu sözleri ile ifade eder:

Sen hiç kimsenin olmayacağı kadar çok şeyimsin benim. Yüreğimde sana ayrılan yer herkesinkinden büyük. Yalnızca bir arkadaş,

34 Buket Uzuner, Kumral Ada Mavi Tuna, s. 418.

35 Zehra Yaşın Dökmen, "Bem Cinsiyet Rolü Envanteri Kadınsılık ve Erkeksilik Ölçekleri Türkçe Formunun Psikometrik Özellikleri”, s. 35.

36 Zehra Yaşın Dökmen, Toplumsal Cinsiyet Sosyal Psikolojik Açıklamalar, s. 35.

37 Buket Uzuner, Kumral Ada Mavi Tuna, s. 111.

38 Buket Uzuner, Kumral Ada Mavi Tuna, s. 237. 
bir kan kardeş, bir sırdaş, birçok yakın dost değil, bir büyük sevgisin sen... Sonra daimî hayranım ve tabii dokunulmamıs sevgilim... Sen benim masumiyetimsin Tuna... Benim en yakınımsın! Aslında belki öbür yarımsin? ${ }^{[39]}$

Tuna ise Ada'ya duyduğu bağımlılıktan kendini kurtaramaz. Ada Tuna’yı bu çıkmazdan kurtarmak ister. Tuna’ya birlikte olmayı teklif eder. Tuna, Ada’yı zorlamak istemez ancak Ada "Hayır, bunu denemek zorundayız Tuna! Senin kendi yaşamını kurmana daha fazla engel olmak istemiyorum" "40] der. Bunu sırf Tuna'ya duyduğu şefkat ve merhametten dolayı yapmak istediği anlaşılır. Romanda yer alan bu ifadelerden, Ada’nın; kadınsılık özellikleri olarak kabul edilen, şefkatli, merhametli, incinmiş duyguları teselli etmeye istekli olmak ${ }^{[41]}$ gibi özellikleri de taşıdığı anlaşılmaktadır.

Toplumun kadından beklentisi yüzyıllardır kadının özel alanda var olması yönünde olmuştur. İyi eş, iyi anne, ev işlerinden sorumlu olma, bakım verme gibi özel alana hapsolmuş roller halen günümüzde kadından beklenir. Özel alana hapsolmuş kadının, kamusal alanda görünürlüğü daima erkeklerin gerisinde kalmıştır. Kadının kamusal alandan uzaklaştırılması ile kamusal alan neredeyse tamamen erkek egemenliğinde olmuştur. ${ }^{[42]} 18$. yüzyıl ortalarından itibaren ve özellikle 19. yüzyıl başında yaşanan tarihsel dönüşümler ile kadınlar bulundukları konumu sorgulamışlar ve konumlarını iyileștirmek amacıyla mücadelede bulunmaya başlamışlardır. Köklerini 19. yüzyıl sonlarına dayandırabileceğimiz Feminizm ile kadınlar kendilerine yüklenen rollere, sorumluluklara tepki vermeye başlamışlardır. Kadının siyasi, ekonomik ve sosyal yönlerden ikincil konumda kalmaları eleştirilmiştir. Romanda yer alan Ada karakterinin, fotoğraf sanatı ile ilgilenmesi ve bu alanda kendini geliştirmesinin ardında bu sorgulamanın var olduğu görülür: "Bizim memlekette neden bir dişi Ara Güler yok? diye sordum durdum kendi kendime günlerce... Ara Güler'den beri kaç tane uluslararası fotoğrafçı çıkarttık ve kaçı kadın? Ezbere sayabilir misiniz" ${ }^{[43]}$ ifadelerini kullanan Ada’nın fotoğrafçılık alanında kadının ikincil konumda kalmış olmasını eleştirdiği anlaşılır. Bu da Ada’nın feminist bir bakış açısına sahip olduğunu gösterir. Ada bu durumu eleştirmenin ötesinde kadın olarak başarılı bir fotoğrafçı olmak için elinden geleni yapar.

Romanda yer alan ifadelere dayanarak, Ada’nın hem erkeksi hem de kadınsı özelliklerinin olduğu görülür. Güzel olmak, alımlı olmak, çekici ve etkileyici ol-

39 Buket Uzuner, Kumral Ada Mavi Tuna, s. 363.

40 Buket Uzuner, Kumral Ada Mavi Tuna, s. 368.

41 Zehra Yaşın Dökmen, Toplumsal Cinsiyet Sosyal Psikolojik Açılklamalar, s. 35.

42 Özlem Çakır, "Türkiye'de Kadının Çalışma Yaşamından Dışlanması”, Iktisadi Idari Bilimler Fakültesi Dergisi, 31, 2008, s. 15.

43 Buket Uzuner, Kumral Ada Mavi Tuna, s. 301. 
mak, dişi ve seksi olmak, merhametli ve şefkatli olmak gibi kadınsı özelliklerinin bulunduğu ifade edilebilir. Bunun yanında kararlı olmak, lider olmak, rekabetçi olmak, başarılı olmak, cesur ve cüretkâr olmak, kendi geçimini sağlamak, özgüvenli olmak gibi erkeksi özelliklere de sahip olduğu söylenebilir. Ada'nın olayları değerlendirirken feminist bakış açısına sahip olduğu hissedilir.

\section{Aras}

Aras, Tuna’nın öz ağabeyidir. Aras kendine güvenen, güçlü bir karakterdir. Tuna Aras'ı "Akılcı, atik, zeki, güçlü Aras! Her zaman beğenilen, başarılı ve özgüvenli ağabeyim" "[4]] şeklinde tanıtır. Tuna, ilk gördüğü anda Ada’ya, Ada ve Aras ise birbirlerine âşık olmuştur. Tuna, çocukluklarında sürekli rekabet halinde olan Aras ve Ada'nın birbirlerine çok benzediklerini ifade eder. Aras daha küçükken bu rekabette galip olabilmek için elinden geleni yapar. Kardeşinin Ada'ya ne kadar bağlı olduğunu bilmesine rağmen, onu Ada'dan korumaya, hatta uzaklaştırmaya çalışır. Tuna’nın Ada’yla oyun oynadığı bir gün kardeşine, "Artık kızlarla oynama yaşın geçti! Artık erkeklerle oynayacaksın”"[45] der. Aras'ın 'kızlarla' diye tabir ettiği kişi aslında yalnızca Ada’ır. Tuna bulduğu her fırsatta Ada ile zaman geçirdiği için Aras bu durumu sindiremez. Bunu gurur meselesi haline getirir. Üzüntüden kahrolan Tuna, ağabeyinin bu tutumunu aşağıdaki cümlelerle açıklar:

Ada ortaya çıkıp, mahallede ilgi uyandırmaya başladıktan sonra, kendi ünü gölgelenen Aras'in rahatı kaçmıştı. Henüz yeni yeni ayrımına vardığı cinsiyetine toplumun yüklediği abartılı ayrıcalıklara sığınacak kadar Ada'dan çekindiğini daha sonraları anlayacaktım. ${ }^{[46]}$

Serpil Sancar erkeklik tanımını "sürekli başka konumların ne olduğu hakkında konuşma hakkını kendi elinde tutan ve bu sayede kendi bulunduğu konum sorgulama dışı kalan bir iktidar konumudur" şeklinde ifade eder. ${ }^{[4]}$ Erkeklik çalışmalarında ilk kez kullanılan bir kavram olan "hegemonik erkekliği” Connell, diğerlerine karşı kazanılmış bir "güç" olarak açıklamaktadır. Connell "Acımasız iktidar çekişmelerinin ötesine geçerek özel yaşamın ve kültürel süreçlerin örgütlenmesine sızan, toplumsal güçler oyununda kazanılan toplumsal üstünlüktür”"[48] ifadelerini kullanır. Aras’ın kardeşinin kızlarla (özellikle Ada’yla) oynamasını engellemek istemesi, Tuna’nın ifadesiyle kendi ününün gölgelenmesine tahammül edememesindendir. Ününü gölgeleyen, ondan daha fazla dikkat çeken bir kız olan Ada’nın

44 Buket Uzuner, Kumral Ada Mavi Tuna, s. 61.

45 Buket Uzuner, Kumral Ada Mavi Tuna, s. 106.

46 Buket Uzuner, Kumral Ada Mavi Tuna, s. 107.

47 Serpil Sancar, Erkeklik: Imkansız Iktidar, Metis Yayınları, İstanbul 2011, s. 16.

48 William Raewny Connell, Toplumsal Cinsiyet ve Iktidar Toplum, Kişi ve Cinsel Politika, Cem Soydemir (çev.), Ayrıntı Yayınevi, İstanbul 2019, s. 269. 
üstünlügünü kabullenememektedir. Çünkü üstünlük kişiye güç kazandıran bir özelliktir. Aras'in korkusu ise bu gücün zayıflaması ve kaybedilmesidir. Cinsiyet kimliği kişinin kim olduğunun önemli bir parçasıdır ve 3-4 yaşlarında gelişmeye başlar. ${ }^{[49]}$ Yukarıda yer alan örnek ifadelerden Aras'in cinsiyet kimlik ediniminin başlamış olduğu anlaşılır. Aras'ı Cornell'in tarif ettiği "toplumsal üstünlügüü henüz küçük yaşlardan itibaren elde etmeye çalışan bir karakter olarak ifade etmek mümkündür.

Ada, Aras’in çocukken kendini üstün gören tutumunu asla kabullenmez ve ona kafa tutmaktan vazgeçmez. Çocukluklarında geçen bir tartışmada Ada, Aras'a "Sen kendini ne sanıyorsun bakalım! Daha okuma yazmayı sökmemişsin, sayı saymayı bilmiyorsun! Türkiye’nin komşularını tanımıyorsun bile... Sen daha çocuksun"[50] der. Buna fena halde bozulan Aras, Tuna’nın ifadesiyle en büyük kozunu oynar ve "Ben bunları nasılsa öğreneceğim, ama sen hiçbir zaman erkek olamayacaksın işte" ${ }^{[51]}$ der. Ada ile tartışmalarında Aras'ın kurduğu bu cümle, Aras'ın 'erkek' olmasindan kaynaklanan toplumsal üstünlügünü ne denli önemsediğini ispatlar. Ona göre bir kızın ondan daha bilgili olmasının bir önemi yoktur. Erkek olduğu için zaten o her zaman bir adım öndedir.

Aras erkek olması ile övünürken; Ada’nın Aras’a verdiği "Erkek olmak isteyen kim akıllım? Enayi miyim ben? Hem sonra sünnet falan olacaksınız... Biliyorsun nereni kesiyorlar sünnette..."[52] cevabından bunun o kadar kolay olmadığ1 anlaşlır. Erkeğin 'erkeklik' görevleri çocuk yaşta başlamaktadır. Erkek çocuklarının, kız çocuklarına nazaran, daha aktif ve girişken olmaları beklenmektedir. ${ }^{\text {[33] }}$ Sokağa çıkıp oynamasında, küfürlü konuşmasında, erkek çocuklarıyla kavga etmesinde pek bir sakınca görülmemektedir. ${ }^{[54]}$ Erkek çocuğunun kimlik inşası küçük yaşta şekillenmeye başlar. Türkiye'de erkek çocuktan beklenen ilk büyük girişim, cinsel organına uygulanacak müdahaleyi anlı şanlı kabullenmesidir. Sünnet, Türkiye'de erkek çocuklarının aşması gereken ilk ciddi bedensel aşama olarak algılanmaktadır. ${ }^{[5]}$ Aras’ın da Türkiye'de yaşayan pek çok erkek gibi, erkek olabilmek için bedel ödemesi gerekecektir. Bu bedellerin ise çok da kolay olmayacağını Ada ifade etmektedir.

Toplumsal cinsiyet kalıp yargılarının erkeğe yüklediği rollerden birisi de kor-

49 Zehra Yaşın Dökmen, Toplumsal Cinsiyet Sosyal Psikolojik Açıklamalar, s. 26.

50 Buket Uzuner, Kumral Ada Mavi Tuna, s. 107.

51 Buket Uzuner, Kumral Ada Mavi Tuna, s. 107.

52 Buket Uzuner, Kumral Ada Mavi Tuna, s. 107.

53 Atilla Barutçu, Türkiye'de Erkeklik Inşasının Bedensel ve Toplumsal Aşamaları, (Yayımlanmamış Yüksek Lisans Tezi), Ankara Üniversitesi Sosyal Bilimler Enstitüsü Kadın Çalışmaları Anabilim Dalı, Ankara 2013, s. 7 .

54 Atilla Barutçu, Türkiye'de Erkeklik Inşasının Bedensel ve Toplumsal Aşamaları, s. 7.

55 Atilla Barutçu, Türkiye'de Erkeklik Inşasının Bedensel ve Toplumsal Aşamaları, s. 7. 
kusuz, gözü pek olmaktır. [56] 'Erkek adam korkar mı hiç?' sözü dillere pelesenk olmuş, henüz konuşmayı bile bilmeyen erkek çocuklara en ufak bir korku belirtisinde söylenegelmiştir. Erkekler bu algıla büyütülürken korksalar bile bunu göstermeyi utanç verici bir durum olarak görürler. Korksalar bile bunu kesinlikle belli etmemeye çalışırlar. Bunun bir örneğini romanda Aras karakterinde görmek mümkündür. "Yutkunarak korkusunu gizleyen Aras, hiç takmıyormuş gibi davrandıysa da bükemediği bir bilekle karşı karşıya kaldığını ikimiz de anlamıştık"[57] ifadeleri Aras'ın 'korkusuz ve gözü pek olmak' gibi cinsiyet kalıp yargılarını taşıdığını gösterir.

Yukarıda verilen alıntılardan yola çıkılarak Aras’in erkeksilik özelliklerini büyük ölçüde taşıdığını söylemek uygun olacaktır. Toplumsal cinsiyet kalıp yargılarını belirlemek amacıyla yapılan çalışmalarda erkekler atılgan, korkusuz, akılcı, güvenli, bağımsız, soğukkanlı, güçlü, katı, saldırgan ve aktif olarak tanımlanır. ${ }^{[58]}$ Erkek güçlüdür, erkek korkusuz ve cesurdur toplumsal cinsiyet kalıp yargısının, Aras'ın çocuk yaşına rağmen kişiliğine ne denli yerleşmiş olduğu görülür. Aras'a göre erkek korkusuzdur, erkeğe ağlamak yakışmaz, erkek daima güçlü olmalıdır. Aksine tahammülü yoktur. Romanda yer alan "Dedesi esaretten söz edip ağlayınca Aras bozulur, savaşlar kazanmış koskoca gazi dedesine bunu yakıştıramaz ve odadan kaçard1"[59] ifadeleri bu görüşü destekler niteliktedir.

Aras mahallenin en popüler çocuğudur. Tuna ağabeyinin popüler oluşunu şu şekilde ifade eder: "Yakışıklılık konusu Aras'ın tekelindeydi; herhangi bir yere adım atar atmaz yakışıklılığı ve erkeksi varlığı hemen fark edilir, adeta ortamın atmosferi değişirdi. İstisnasız bütün kızlar mutlaka ağabeyime dönüp dönüp bakarlardı"[60] Tuna, ağabeyinin yakışıklı ve erkeksi özelliklerinin Aras'ın popüler olmasına olanak sağladığını ifade eder. Tuna ağabeyini anlatırken "Aras'ın arkadaş sıkıntısı çektiği görülmüş değildi. Cesurdu Aras. Gözüpek ve atak. Adildi ve akıllıydı. Tam bir liderdi. Mahallede onunla oynamak, onun tarafından kabul görmek bir onurdu"[61] cümlelerini kullanır. Aras, taşımış olduğu erkeksi özellikler sayesinde mahallede ilgi gören bir karakterdir.

Daha çok erkeklere yakıştırılan "ciddiyet" kalıp yargısının ${ }^{[62]}$ Aras karakterinde bulunduğu görülür. "Onun yüzünde elde edilmesi güç olduğuna dair baştan çı-

\footnotetext{
56 Ayşe Nur Kavuncu, Bem Cinsiyet Rolü Envanteri’ni Türk Toplumuna Uyarlama Çalışmaları, s. 56.

57 Buket Uzuner, Kumral Ada Mavi Tuna, s. 107.

58 Nuray Sakallıŏlu ve Beril Türkoğlu, "Erkek Olmak ya da Olmamak: Sosyal Psikolojik Açıdan Erkeksilik/ Erkeklik Çalışmaları”, Türk Psikoloji Yazıları, 22/44, 2019, s. 53.

59 Buket Uzuner, Kumral Ada Mavi Tuna, s. 53.

60 Buket Uzuner, Kumral Ada Mavi Tuna, s. 200.

61 Buket Uzuner, Kumral Ada Mavi Tuna, s. 62.

62 Zehra Yaşın Dökmen, Toplumsal Cinsiyet Sosyal Psikolojik Açıklamalar, s. 37.
} 
kartıcı ciddi bir ifade vardı"[63] Tuna, ağabeyi Aras'ın ciddi tavırlarının etrafındaki kızları etkilendiğini düşünmektedir. Bu yönüyle de Aras erkeksi cinsiyet kalıp yargilarına uymaktadır.

Toplumda kadın ve erkek birbirlerine göre karşı cinsi ifade ettikleri için, karşı cinsin sahip olduğu özelliklerin zıddı ile tanımlanırlar. Örneğin kadın cesur olmayandır, kaba saba konuşmayandır; erkekse duygulu olmayandır, narin ve nazik davranmayandır. ${ }^{[64]}$ Toplumsal cinsiyet kalıp yargılarına göre narin olmaması gereken bir erkek dayanıklı olmalıdır. Aras'ın Tuna'ya söylediği "Aman be Tuna, biraz dayanıklı ol be! Erkek adam olacaksın"[65] cümlesinden 'erkek olacak adamın' dayanıklı olma zorunluluğu vardır yargısı çıkarılabilir. Aras dayanıklı olmak kalıp yargısını taşıyan ve savunan bir karakterdir. Tuna "Bazen onu tahtından indirmek isteyen çocuklar peydahlanır, ama bütün oyun ve yarışlarda kimse Aras’ın bileğini bükemezdi’"[66] ifadelerini kullanır. Bu ifadelerden de anlaşılacağı üzere Aras’n güçlü ve hırslı bir karakter olduğu görülür. Bu yönüyle toplumsal cinsiyet kalıp yargılarının erkeklere yüklediği erkeksilik özelliklerinden 'güçlü olmak', 'dayanıklı olmak' ve 'hırslı olmak' kalıp yargılarını taşıdığı görülür. Oyunlarda bile hırslıdır, yenilmezdir, yenilmeyi kabul edemeyecek kadar gururludur.

Toplumda kız ve erkek çocuklarının ilgi alanlarında da farklılıklar olduğu görülmektedir. Basow kitabında oğlan çocukların matematik ve görsel uzamsal becerilerde üstün olmalarının beklendiğini; bu nedenle oğlanların bu becerileri geliştiren etkinliklere özendirildiğini ve daha çok bu alanlarda deneyim sahibi olduklarını ifade eder. ${ }^{[67]}$ Aras'ın da matematik ve fen bilimlerinde başarılı ve ilgili bir öğrenci olduğu görülür. "Cebir on, kimya on, geometri on, demek ki fizik de on oldu şimdi..."[68] Aras'ın bu derslerde başarılı olması da erkeklerden beklenilen becerilere sahip olduğunu göstermektedir.

Toplumsal cinsiyet kalıp yargılarının kız ve erkek çocuklarının meslek seçimlerini etkilediği bilinmektedir. Bu doğrultuda kadınların meslek olarak öğretmenlik, hemşirelik, sosyal çalışmacı, doktor vb. alanları seçmesi, gerektiğinde evine ve çocuklarına öncelikli olarak vakit ayırabilmesi, erkeklerin ise aktif ve güçlü olabilecekleri yöneticilik, askerlik, polislik, mühendislik vb. mesleklere yönelmesi kabul

63 Buket Uzuner, Kumral Ada Mavi Tuna, s. 17.

64 Zehra Yaşın Dökmen, Toplumsal Cinsiyet Sosyal Psikolojik Açıklamalar, s. 104.

65 Buket Uzuner, Kumral Ada Mavi Tuna, s. 266.

66 Buket Uzuner, Kumral Ada Mavi Tuna, s. 62.

67 Susan Basow, Gender Stereotypes and Roles, Brooks/Cole Publishing Company, California 1992, s. 52.

68 Buket Uzuner, Kumral Ada Mavi Tuna, s. 218. 
görmektedir. ${ }^{[69]}$ Toplumsal cinsiyet kalıp yargılarını küçük yaşlardan itibaren içselleştirdiğini söyleyebileceğimiz Aras’in da meslek seçimi gemi inşaat mühendisliği olacaktır. Aras bu bölümü bitirerek deniz subayı olmayı planlamaktadır. Tuna ağabeyi ile ilgili "Yetenekliydi Aras. Saatlerce sabırla uğraşarak kartondan oyuncaklar yapardı. Günlerce çalışarak tamamladığı maket uçak ve gemileri, ince ayrıntılarıyla görenleri hayran bırakırdı. Denizaltı ve gemilere aşırı düşkündü..." ${ }^{\text {70] }}$ ifadelerini kullanır. Bir başka yerde Aras "Ben, dedi usulca. Ben teknik üniversitede gemi inşaat mühendisliği okuyacağım"[71] der. Verilen bu cümlelerden, Aras'ın meslek seçimi hakkında düşüncelerini anlamak mümkündür. Mühendislik ve subaylık daha çok erkeklerin tercih ettikleri mesleklerdir. Buna göre romanda yer alan bu ifadelerden, Aras'in meslek seçiminde ve bu doğrultuda yaptığ çalışmalarda erkeksi özellikler ile uyumlu olduğu görülür.

Toplumsal cinsiyet kalıp yargılarına göre kız ve erkeklerin oynadıkları oyunlar da farklıdır. Kız çocuklar daha çok bebekleriyle oynamak, evcilik oynamak gibi oyunlar tercih ederler. Erkek çocuklar ise silah, araba, uçak gibi oyuncaklarla oynarlar. Aras oynadığı oyunlarda dahi kızların oynadığı oyunları tercih etmez. Bunu romanda yer alan "Kızlar daha çok şıpşıp ve seksek oynamayı, ip atlamayı seviyorlardı ve Aras bunları bir kez bile denememiști" [72] ifadeleri ve "O hemen odamıza çekilir ya maket yapar ya bilim teknik dergileri okur ya da uçak ve gemi resimleri çizerdi.... ${ }^{\text {[73] }}$ cümlelerinden anlamak mümkündür. Aras'ın oynadığı oyunlarla da erkeksi rollere uyumlu olduğu söylenebilir.

Aras’ın erkeksi özellikle arasında yer alan atletik ve sportif olma özelliklerini taşıdığını, "...çok iyi yüzer, ağaçların en üst dallarına tırmanabilir, kocaman taşları kaldırabilirdi”[74] ifadelerinden çıkarmak mümkündür. Büyüyüp genç bir oğlan olduğunda Aras'ın bu yönü hayatına sebep olacaktır. Ada ile birlikte oldukları günün akşamında hava serin olmasına rağmen denizde yüzebileceğini söyler. Tuna’nın havanın yüzmek için uygun olmadığını söylemesi üzerine "Süt kuzusu olma be oğlum, kızlar kuvvetli erkek severler..." ${ }^{[75]}$ der. Tuna bu acı olayı "Aras, Ada’nın yanağından bir makas aldı. Ada cilveyle gülümsedi ve ağbim denize doğru koştu. Kör

69 Helen Watt, "Gender and Occupational Choice”, Handbook of Gender Research in Psychology (Chapter 16) J.C.Chrisler and D.R McCreary (eds.), Springer Science Business Media, s. 379. https://www.researchgate. net/publication/270342201_Watt_HMG_2010_Gender_and_occupational_choice_In_J_C_Chrisler_D_R_ McCreary_Eds_Handbook_of_gender_research_in_Psychology_Ch_16_pp_379-400_New_York_Springer,(27.10.2020).

70 Buket Uzuner, Kumral Ada Mavi Tuna, s. 62.

71 Buket Uzuner, Kumral Ada Mavi Tuna, s. 219.

72 Buket Uzuner, Kumral Ada Mavi Tuna, s. 107.

73 Buket Uzuner, Kumral Ada Mavi Tuna, s. 208.

74 Buket Uzuner, Kumral Ada Mavi Tuna, s. 62.

75 Buket Uzuner, Kumral Ada Mavi Tuna, s. 266. 
uçuşu balıklama atladı”"[76] cümleleriyle anlatır. Bu atlayış Aras'ın sonu olur. Aras'ın erkekliğin ispatı olarak gördüğü ve ölümüne sebep olan güç gösterisi, toplumsal cinsiyet rollerini hayatı pahasına içselleştirdiğini göstermektedir.

Erkeklerden beklenen toplumsal cinsiyet rollerinden biri de para kazanıp, evinin geçimini sağlamasıdır. ${ }^{[77]}$ Küçük yaşlardan itibaren erkek çocuklar para kazanmanın, aileyi geçindirmenin önemli bir vazife olduğunu görerek büyürler. Hatta gençlik döneminde iş öğrensin, eli ekmek tutsun gibi söylemlerle erkeklerin çeşitli alanlarda çalışmaya başlaması oldukça yaygındır. Ailesinin geçimine katkı sağlayan genç erkekler takdirle karşılanır. Aras karakterinin lise yıllarında para kazanmaya başlayan bir erkek olduğunu "Aras lise birden bir çocuğa fizik dersi veriyordu. On altı yaşındaydı ve para kazanıyordu"[78] cümlelerinden anlaşılmaktadır. Para kazanmaya başlayan Aras’ın 'hesabı erkek öder' kalıp yargısını da içselleştiren bir karakter olduğu anlaşılmaktadır. "Kasaya üç Kup Griye ödemek için paralarımızı birleştirecekken, Aras biraz da hava atarak, 'Ben öderim!' dedi”'[79] ifadelerinden anlaşılacağı üzere Aras'in toplumsal cinsiyetin erkekten beklenen, para kazanmak, hesap ödetmemek gibi kalıp yargıları benimseyen bir karakter olduğu görülür.

Verilen örneklerden anlaşılacağı üzere Aras; yakışıklı, zeki, başarılı, kendine güvenen, güçlü, atletik, popüler, sportif, korkusuz, hırsl, ciddi gibi erkeksi özelliklerin çoğunu taşıyan bir karakterdir. Hatta hegemonik erkekliği temsil eden bir karakter olduğu söylenebilir. Bu anlamda Aras, toplumun beklentilerini yansıtan bir ayna gibidir.

\section{Tuna}

Tuna bu romanın başkişisidir. Olayların çoğu Tuna’nın ağzından anlatılmaktadır. Tuna, evin iki erkek çocuğundan küçük olanıdır. Ağabeyi Aras’ın tersine naif, hassas, duygusal bir erkektir. Ada’ya âşıktır ancak Ada’nın kuzeni Meriç’le evlenmiştir.

Ağabeyi Aras'ın, Ada ile birlikte olduğu gece, denize atlayarak ölmesinden sonra Tuna da çok zor zamanlar geçirmiştir. Tuna’nın üzüntüsü hem ağabeyine duyduğu acı hem de Ada’nın bu olaydan sonra yaşadığı şok sonrası toparlanamamasından duyduğu üzüntü ile ikiye katlanmıştır. Ada bu olaydan dolayı kendini suçlamış, Aras’a engel olmadığı için kendini Aras’ın ölümünden sorumlu tutmuştur. Oysa Tuna olayın şahidi olarak, Ada’nın ya da kendisinin bu olayda bir suçu

76 Buket Uzuner, Kumral Ada Mavi Tuna, s. 267.

77 Celaleddin Vatandaş, "Toplumsal Cinsiyet ve Cinsiyet Rollerinin Algılanışı", s. 41.

78 Buket Uzuner, Kumral Ada Mavi Tuna, s. 225.

79 Buket Uzuner, Kumral Ada Mavi Tuna, s. 225. 
olmadığını bilmektedir. Tuna bir sabah gazetede sevdiği kadın Ada’nın cinayet işlediğine dair bir haber görür ve beyninden vurulmuşa döner. Hassas yapısı artık olanları kaldıramaz ve büyük bir ruhsal bunalıma girer.

Kendisi bir gün böyle bir çöküntü yaşayacağının farkındadır. Kendisini almaya gelen iki askere (romanda asker olarak yer alır, Tuna'yı almaya gelenlerin ruh hastanesinden gelen sağlık görevlileri olduğu ifade edilebilir) şöyle söyler:

"Bunu bekliyordum", dedi Tuna, dalgın dalgın bakarak, "Bunu bekliyordum...” Yıllardır kuşkuyla bekliyordum. Çünkü dışarda birileri ölürken, hiçbirimizin içi temiz kalamazdı!”

Arkasını döndü.

Ve içindeki bütün lifler koptu. ${ }^{[80]}$

Tuna’nın yaşadığı bu ruhsal çöküntünün onun hassas ve duygusal karakteriyle ilgili olduğu söylenebilir. Hassas karakteri yaşadı̆̆ı olayları bertaraf etmekte hayli zorlanmıştır. Bu bunalıma da bu yüzden girmiştir denilebilir.

Tuna’nın hassas ve duyarlı bir karakter olduğuna romanın birçok yerinde rastlamak mümkündür. Tuna etrafında gördüğü, duyduğu, okuduğu tüm olumsuz olaylardan etkilenmektedir. Bu olumsuzluklar onun ruhunda derin etkiler yaratmaktadır. Romanda yer alan aşağıdaki cümleler Tuna’nın ruh halini ifade eder:

Aslında yaşadığı bu yoğun taarruz yeni değildi. Uzun zamandır düşünceleri içten içe onu kemiriyor, yıpratıp yiyip bitiriyordu. Kendi düşüncelerinden kaçıp kurtulamıyor, düşüncelerinin yarattığ 1 korku, endişe ve tehdit duygularını söküp atamıyordu. Düşüncelerinin ve endişelerinin esiri olduğunu hissediyordu. Konuşabileceği tek kişi Ada'ydı ama onu da bıktırmaktan çekiniyordu. Her şey endişe vericiydi. Evde, okulda, kendi içinde, sokakta, kentte, ülkede ve dünyada olanlar kimi kez başa çıkamayacağı kadar karmaşık, ilkel, barbar, çirkin ve yakışıksız, kimi kez hiçbir mantık, doğa ya da fizik yasasıyla açıklanamayacak kadar anlamsız ve dehşet vericiydi. Yeni fikir ve projeler üreterek çözümler geliştirmeye çalışıyor, hatta bazen umutlanıyor, öğrencilerine ve ailesine umut veriyor, ama o sırada yeniden patlak veren bir şiddet, bir sömürü ya da vurdumduymazlikla tekrar iflas ediyordu. ${ }^{[81]}$

80 Buket Uzuner, Kumral Ada Mavi Tuna, s. 17.

81 Buket Uzuner, Kumral Ada Mavi Tuna, s. 47-48. 
Tuna’nın ne kadar hassas ve duyarlı bir yapısının olduğu yukarıdaki ifadelerden anlaşılmaktadır. Dünyadaki tüm kötülükler onun ruhunda gedikler açmaktadır. Gazetede okuduğu savaş, şiddet, cinayet haberleri onu son derece sarsmaktadır. Yine böyle haberler okuduğu bir gün "Allah kahretsin! diye dişlerinin arasından tükürür gibi söylendi. Dışarıda hep birileri ölüyor" ${ }^{[82]}$ der. Romanda yer alan "Gazetelerdeki haberler midesini bulandırıyordu"[83] cümlelerinden Tuna’nın kendi dişında bile gelişse tüm kötülüklerden, ölümlerden, cinayetlerden dolayı hissettiği üzüntü anlaşılır. Duyarlı ve hassas olmak bir kadından beklenen kalıp yargılardandır. ${ }^{[84]} \mathrm{Bu}$ anlamda Tuna’nın kadınsı özellikler olan hassas ve duyarlı olmak özelliklerini taşıdığı görülür.

Tuna’nın kendisini bir iç savaşın ortasında tahayyül ettiği bölümlerde, ne kadar korku dolu zamanlar geçirdiği görülür. Bu iç savaşta karşısına, bazı çocukluk arkadaşları ile tanımadığı farklı insanlar çıkar. Tuna, bunun gerçek bir savaş olmadığına hem kendini hem de etrafındakileri ikna etmeye çabalar. Beyninin ve bilinçaltının etkisinde kalarak, kendi kurgusu olan kötü bir kâbus gördüğüne inanır. Bu savaşta Tuna da herkes gibi asker olarak seferber olmuştur. Çocukluk arkadaşı Sefer ile karşılaştığını tahayyül eder. Sefer'e de böyle bir savaşın çıkmadığını, her şeyin kendi beyninin bir oyunu olduğunu söyler. Tuna Sefer'in kendisine “Bana baksana sen Tuna! Yav sen keçileri mi kaçırdın, rol mü yapıyorsun? Ne biçim erkeksin sen arkadaş? Korkuyor musun yoksa"[85] dediğini düşünür. Askerlik, erkeklerin erkeklik inşa sürecinde geçmeleri gereken bir adım olarak karşımıza çıkmaktadır. Bu hizmetin yapılmasının erkeğin erkekliğine değer kattığ 1 düşünülür. Askere gitmeyen erkek zorluklarla savaşmada yetersiz kaldığı için erkekler cemiyetinde kendine alt sıralarda yer bulur ve hegemonik erkekliğe ulaşmada başarısız kalır. ${ }^{[86]}$ Arkadaşı Sefer'in, Tuna’nın yaşadığı bu bunalımda, onun erkekliğini sorgulamasındaki neden olarak bu görüşün etkili olduğu söylenebilir. Tuna çocukluk arkadaşı Sefer'in, seferberlikte askerlikten ve savaştan korkuyor olmasını eleştirdiğini düşünür. Türkiye'de toplumsal cinsiyet kalıp yargılarına göre bir erkeğin tam anlamıyla erkek olabilmesi için nasıl ki sünnet olması, heteroseksüel cinsel tercihinin olması gerekiyorsa, askerliğini de yapmış olması gerekir. Gerektiğinde ve çağrıldığında asker olmaktan kaçmak ya da askere gitmemek erkeklik algısı açısından hoş karşılanmaz. Tuna ise şu şekilde karşılık verir:

Evet, korkuyorum Sefer. Hem de çok korkuyorum. Eğer gerçekten bir iç savaş yaşıyorsak, neden konuşmuyoruz, niçin görmezden geliyoruz diye korkuyorum... Yaşamıyorsak... Yaşamıyorsak

\footnotetext{
82 Buket Uzuner, Kumral Ada Mavi Tuna, s. 12.

83 Buket Uzuner, Kumral Ada Mavi Tuna, s. 12-13.

84 Zehra Yaşın Dökmen, Toplumsal Cinsiyet Sosyal Psikolojik Açıklamalar, s. 35.

85 Buket Uzuner, Kumral Ada Mavi Tuna, s. 92.

86 Atilla Barutçu, Türkiye'de Erkeklik Inşasının Bedensel ve Toplumsal Aşamaları, s. 62-63.
} 
o zaman bu kâbusu başıma açan beynimin intikamından korkuyorum. ${ }^{[87]}$

Tuna’nın hassas kişiliği böyle bir savaşı kabul etmekte zorlanır. Savaştan, ölümden, şiddetten nefret ettiğini ve korktuğunu ifade eder. "Şiddetten nefret eden bir beynin, endişe ve panik duyguları içinde yazdığ bir senaryo"[88] sözleriyle hem şiddetten nefret ettiğini hem de böyle bir savaşın aslında var olmadığını düşündüğü anlaşılır. "Bütün suç bende. Hepsini benim korkularım, benim savaştan, şiddetten nefretim yarattı" [89] der. Küçükken dedesine sorduğu "Savaş öyküleri sevmeyen biri erkek olamaz mı dede" ${ }^{[90]}$ sorusundan savaş öykülerinden dahi hoşlanmadığı anlaşılır. "Savaş romanlarını ve filmlerini sevmezdi..." ${ }^{\text {[11] }}$ cümlelerinde genellikle erkeklerin tercih ettiği savaş ve aksiyon filmlerini ve savaş kitaplarını sevmediği anlaşılır. Savaşta bombaların atıldığı, insanların öldürüldüğünü tahayyül ederken nefretini haykırır:

Hadi konuşsanıza bebek kasapları! Nasıl kesiyorsunuz bebekleri kıtır kıtır ha? Bombalarla, yangınlarla nasıl kıyıyorsunuz insanlara ha? Nasıl öğrendiniz öldürmeyi inancınız uğruna ha? Böyle inanc1nızın Allah belasını versin be! ${ }^{[92]}$

Tuna’nın yukarıdaki ifadeleri savaşa, savaşta yapılan kıyıma duyduğu nefretin bir göstergesidir. Erkeksi özellikler arasında yer aldığı kabul edilen saldırganlık, savaşa ve kavgaya katılmak gibi ${ }^{[93]}$ cinsiyet kalıp yargılarının Tuna’da bulunmadığı, aksine Tuna'nın naif, kavgadan kaçınan, şiddetten nefret eden bir karakter olduğu görülür. Bu anlamda da erkeksi özellikler taşımadığını söylemek mümkündür.

Tuna'nın çekingen ve utangaç bir yapısının olduğu romanda yer alan olaylarda fark edilir. Tuna geçirdiği bunalımda çocukluk arkadaşı Nesim’le bir tartışma yaşadığını tahayyül eder. Nesim Yahudi kökenli bir arkadaşıdır. Ona bu iç savaşta ne aradığını, neden kaçıp gitmediğini sorar. Nesim'in buna çok bozulduğunu, kendisini ayrımcılıkla suçladığını düşünür. Tuna kendi iç savaşında yaptığı bu davranıştan utanç duyar. Kendini oldukça kötü hisseder. "Utangaç mavi gözlerini nereye saklayacağını bilemeden, beceriksiz hareketlerle gözlügüyle oynadı. Zorda kaldığında hep yaptığg gibi üst üste yutkundu’[94] cümlelerinden Tuna’nın utangaç ve

87 Buket Uzuner, Kumral Ada Mavi Tuna, s. 92.

88 Buket Uzuner, Kumral Ada Mavi Tuna, s. 55.

89 Buket Uzuner, Kumral Ada Mavi Tuna, s. 55.

90 Buket Uzuner, Kumral Ada Mavi Tuna, s. 50.

91 Buket Uzuner, Kumral Ada Mavi Tuna, s. 145.

92 Buket Uzuner, Kumral Ada Mavi Tuna, s. 192.

93 Zehra Yaşın Dökmen, Toplumsal Cinsiyet Sosyal Psikolojik Açıklamalar, s. 58-161.

94 Buket Uzuner, Kumral Ada Mavi Tuna, s. 155. 
çekingen bir karakter olduğu görülür. Çekingenlik ve utangaçlık kadınsı özellikler olarak karşımıza çıkmaktadır. ${ }^{[95]} \mathrm{Bu}$ anlamda Tuna’nın kadınsı olan bu özelliklere sahip olduğu görülür.

Tuna’nın çekingenliğinin yanı sıra özgüveninin de düşük olduğu romanda fark edilen özelliklerindendir. Tuna Ada'ya âşık olmasına karşın kendisini ona layık görmemektedir. Ancak Ada'dan uzaklaşacak cesareti de kendinde bulamaz. "İnsan acı çektiği durumu ya düzeltmeli ya da oradan ayrılmalıdır. Ben ikisini de yapamadan acı çekiyordum... Sevdiğim kişinin de beni sevmesini şiddetle arzu ediyor, ama kendimi ona layık bulmuyordum"[96] Tuna'nın bu ifadelerinden özgüveni düşük bir erkek olduğu hissedilir. Tuna erkeksi özelliklerden sayılan özgüvenli olmak özelliğini taşımamaktadır.

Tuna kolay ağlayan bir erkektir. 'Erkekler ağlamaz' kalıp yargısının aksine romanda pek çok yerde Tuna’nın ağladığı ifadeleri yer alır. Dedesinin ölümünden sonra kendisine teselli vermeye çalışan Ada’nın dayısı şair Doğan Gökay’a duygusuz olduğunu söyler. Bu sözünün hemen ardından müthiş bir pişmanlık duyar. Hislerini şu cümlelerle dile getirir:

Birden çok utandım. Feci utandım. Kendimi zayıf ve çaresiz hissettim. Böyle hissettikçe kederim artıyor, daha çok bocalıyor ve çuvallıyordum. Her şey üstüme üstüme geliyordu. Daha fazla dayanamadım ve ağlamaya başladım. ${ }^{\text {[97] }}$

Tuna, zayıf ve çaresiz hissettiğini belirtir. Tuna’nın ruhsal bunalım geçirirken de sık sık ağladığı görülür. "Kan, ter, gözyaşıyla ıslanan bedeni sarsılarak ağlamaya başladı"[98] cümleleri Tuna’nın zor zamanlarında ağladığını gösterir. Kolay ağlamak da kadınsı özellikler arasında yer alan özelliklerdendir. ${ }^{[99]} \mathrm{Bu}$ cümlelerden yola çıkılarak Tuna’nın, kadınsı sayılan bu özelliğe de sahip bir karakter olduğu görülür.

Romanın birçok yerinde Tuna’nın korkularına rastlamak mümkündür. Ada ile tanıştıkları gün bahçede Adalar’ın köpeği Sivri'yi görür. Ada ile tanışıp arkadaş olduktan sonra sık sık bahçelerinde oyun oynarlar ancak Tuna Sivri'ye alışamamıştır. "Ada’ya mahcup olmamak için köpeklerden korktuğumu söyleyemiyor, ödüm patlayarak Sivri'ye katlanmak zorunda kalıyordum"[100] cümleleri ile Tuna’nın

95 Ramazan Akdoğan ve Gürhan Can, “Utangaçlıkta Cinsiyet Rolü Bir Risk Faktörü mü?”, İstanbul Üniversitesi Kadın Araştırmaları Dergisi, 2019, s. 10-11.

96 Buket Uzuner, Kumral Ada Mavi Tuna, s. 266.

97 Buket Uzuner, Kumral Ada Mavi Tuna, s. 231.

98 Buket Uzuner, Kumral Ada Mavi Tuna, s. 334.

99 Celaleddin Vatandaş, "Toplumsal Cinsiyet ve Cinsiyet Rollerinin Algılanışı”, s. 45.

100 Buket Uzuner, Kumral Ada Mavi Tuna, s. 79. 
köpekten korktuğu anlaşılır. Ada Tuna’yla arkadaş kalabilmek için üç kertenkele kuyruğunun suyunu içmesini ister. "Önce ağlayacak kadar kötü hissettim kendimi, sonra sarkan dudaklarımı sımsıkı gererek burnumu çektim, dişlerimi sıkarak bu korkunç sınavın korkusuna kapıldım" [101] cümleleri Ada’nın bu isteğinin onu ne kadar korkuttuğunu gösterir. Tuna’nın hassas kişiliği için bu çok zorlu bir istektir. Ada’yla arkadaş kalabilmek için bu isteği yerine getirmeye çabalar. Kertenkele arar. "Aslında kertenkele bulsam bile yakalayamayacağımı bal gibi biliyordum"[102] ifadelerinde kertenkele bulsa bile yakalayacak cesareti olmadığ ${ }_{1}$ anlaşılır. Nitekim kertenkeleleri ağabeyi Aras, Tuna için yakalar. Tuna yetişme sürecinde de erkeksi özellikleri ile dikkat çeken ağabeyinin aksine farklı bir çocuk olarak dikkat çeker.

Tuna oyun oynarken bile erkeklerin oynadığı oyunları tercih etmez. Tuna "Ben ağaçlara tırmanıp, kovboyculuk oynamak yerine, hayaller kurup, filmler izlemeye, masallar dinlemeye bayılırdım. Oynayan çocuklardan biri olmak yerine, onları seyredip, hakkında hikâyeler uydurmayı severdim"'[103] der. Erkek çocuklarda görmeye alıştığımız ve erkek çocuklarla özdeşleşen kovboyculuk oyunu oynamayı sevmez. Ağaçlara tırmanmak gibi daha çok cesaret isteyen oyunlardan hoşlanmaz. Yapılan çalışmalarda, erkeklere daha güçlü oldukları varsayımına dayanarak, fiziksel aktivitesi yüksek oyunların uygun görüldüğünü ifade edersek ${ }^{[104]}$ Tuna’nın hayal kurmak, masal dinlemek gibi fiziksel güç gerektirmeyen oyunlar oynamaktan zevk aldığı anlaşılır.

Tuna tercih ettiği meslek ve yeteneğinin olduğu ilgi alanları bakımından da erkeksi özellikler taşımaz. Romanda yer alan "Ben dedim, atılarak 'ben büyüyünce şair olabilirim' ..."[105], "Evdeki asıl edebiyat tutkunu bendim. Aç kurtlar gibi okurdum... Gizlice şiir yazdığımı da bir tek o biliyordu"[106], "Ertesi gün anneme, büyünce sirklerde çalışan bir şair olmak istediğimi söylediğimde ..."[107] ifadelerden anlaşılacağı üzere Tuna edebiyat tutkunudur. Şiir okumaktan, şiir yazmaktan hoşlanan Tuna’nın mesleği ise edebiyat öğretmenliğidir. Erkeklerden beklenen matematik, görsel-uzamsal becerilerin üstün olmas1 ${ }^{[108]}$ yargısının aksine, Tuna’nın kadınlardan beklenen sözel becerilerde üstün olma özelliği taşıdığı görülür. Ayrıca "Giysi tasarımı konusunda fena sayılmazdım" ${ }^{[109]}$ sözlerinden çoğunlukla

101 Buket Uzuner, Kumral Ada Mavi Tuna, s. 73.

102 Buket Uzuner, Kumral Ada Mavi Tuna, s. 76.

103 Buket Uzuner, Kumral Ada Mavi Tuna, s. 62.

104 Ayşe Nur Kılılıç, vd., "Okul Çağı Çocuklarının Toplumsal Cinsiyet Algıları: Gündelik Yaşam Örnekleriyle Cinsiyetçiliğin Benimsenme Durumuna ve Esneyebilme Olasılığına Dair Bir Araştırma”, Sosyoloji Araştırmaları Dergisi, 17/2, 2014, s. 25.

105 Buket Uzuner, Kumral Ada Mavi Tuna, s. 203.

106 Buket Uzuner, Kumral Ada Mavi Tuna, s. 225.

107 Buket Uzuner, Kumral Ada Mavi Tuna, s. 143.

108 Zehra Yaşın Dökmen, Toplumsal Cinsiyet Sosyal Psikolojik Açılamalar, s. 157-159.

109 Buket Uzuner, Kumral Ada Mavi Tuna, s. 298. 
kadınların ilgi alanı ve tercihi olduğu varsayılan moda tasarımı konusunda başarılı olduğu anlaşılır. Bunlara dayanarak Tuna’nın ilgi alanının, becerilerinin ve meslek seçiminin, kadınsı olduğu kabul edilen özellikler ile uyumlu olduğu görülmektedir.

Güçlü olmak, erkeklerden beklenen en belirgin kalıp yargılardan biridir. Fiziksel anlamda, maddi anlamda, duygusal anlamda erkeklerin güçlü olması beklenir. "Biraz sert ol be koçum, erkek adama yakışır mı zayıflıklar"[110] ifadesi Tuna bunalımdayken arkadaşı Sefer’in Tuna’ya söylediğini düşündüğü sözlerdir. İç savaşı bir türlü kabullenemeyen Tuna, hayalinde canlandırdığı karakterlerle erkekliğini sorgular. Romanda kendisini savaşta zanneden, sık sık da bunun bir rüya olduğunu düşünen Tuna’nın baygınlık geçirdiği ifadeleri yer alır. "Hemen hemen hiç konuşmamış, arada bir fenalık geçirerek 'asker' ve 'erkek' imgesine yakışmayacak zayıflıklar sergilemişti” [111] ifadeleri ağır geçirdiği bunalımda ne kadar güçsüz olduğunu gösterir. Bu kâbusta arkadaşı Musa’nın yaralandığını ve onu taşımak zorunda kaldığını tahayyül eder. Oysa bu Tuna için çok kolay bir iş değildir. "Ama Musa iri yarı, ağır, kendisi ince, zayıf ve çok yorgundu"[112] ifadelerinden de anlaşılacağı üzere fiziksel olarak da güçlü bir karakter değildir. Arkadaşı Musa’yı çekiştire çekiştire taşımak zorunda kaldığını ve sonunda kımıldayamayacak kadar bitkin düştüğünü hisseder. “...ergenlik sivilcelerim ve yaşıma göre ufak tefek, çelimsiz bedenim derken..."[113] ifadelerinden de anlaşılacağı üzere Tuna’nın fiziksel olarak da duygusal olarak da güçlü bir karakter olmadığı görülür. Güçlü olmak erkeksi bir özelliktir ve Tuna’nın bu özelliği taşımadığı görülür.

Toplumsal cinsiyet ilişkilerinin ve kalıp yargılarının ataerkillikten beslendiğini ifade edersek, aile içinde yönetime hâkim bir baba figürünün önemi tartışılmaz bir gerçektir. Ailedeki bireyler babanın yönetimindedir. Geçmişten günümüze erkeğin, toplumsal cinsiyet ilişkileri içerisinde güç, aile reisliği ve babalık gibi faktörler içerisinde sunulduğu görülür. ${ }^{[14]}$ Erkeğin bir kadına sahip olduğunun, kısır olmadığının da bir göstergesi olan babalık rolü toplumda birçok erkeğin sahip olmak istediği bir roldür. Tuna karakteri bu konuda da toplumun beklentilerinin aksine, baba olmayı düşünmemektedir. "Aslında çocuk istemeyen bendim. Çocukları sevmediğimden değil ama... galiba baba olmak fikri beni korkutuyordu"[115] cümlelerinden pek çok erkeğin en büyük gayesi olan babalık rolüne de mesafeli olduğu anlaşılır.

\footnotetext{
110 Buket Uzuner, Kumral Ada Mavi Tuna, s. 95.

111 Buket Uzuner, Kumral Ada Mavi Tuna, s. 135.

112 Buket Uzuner, Kumral Ada Mavi Tuna, s. 190.

113 Buket Uzuner, Kumral Ada Mavi Tuna, s. 199.

114 Hacı Özdemir, "Toplumsal Cinsiyet Perspektifinde Erkeklik ve Kadınlık Algısı Bir Alan Araştırması", Akademik Sosyal Araştırmalar, 10, s. 96.

115 Buket Uzuner, Kumral Ada Mavi Tuna, s. 398.
} 
Erkeklerden iş ve sosyal yaşamda başarılı olmaları, yüksek statü kazanmaları beklenir. Toplum tarafından ailenin ekmeğini kazanması rolü verilen erkek, çok para kazanmak, ailesini en iyi koşullarda yaşatabilmek için ekonomik güç elde etme zorunluluğu duyar. ${ }^{[116]}$ Tuna’nın bir edebiyat öğretmeni olarak, doktor olan Meriç'le evlenmesi kendinden daha yüksek statüde bir kadınla evlilik yapmış olduğunu gösterir. Meriç, Tuna'dan daha yüksek bir kariyerde olmamak için pratisyen olarak kalmayı düşünür. Tuna buna karşı çıkar:

Meriç, biz evlendikten bir yıl sonra okulu bitirmiş ve önceleri pratisyen kalmakta ısrar etmişti. Bunun asıl nedeninin lise öğretmeni kocasının erkek gururunu korumak amaçlı bir özveri olduğunu anladığımda kesinlikle karşı çıktım ona. Gidebildiği yükselebildiği yere kadar onu desteklemeye kararlıydım. ${ }^{[17]}$

Yukarıda yer alan ifadelerden, karısının kendinden yüksek statüde olmasını kabul etmek istemeyen çoğu erkeğin aksine Tuna bu konuda karısına destek olmak isteyen bir kocadır. Bu anlamda da Tuna’nın erkeksi cinsiyet kalıp yargılarına uymayan bir karakter olduğu görülür.

Yukarıda ifade edilen özelliklerin haricinde Tuna'nın son derece merhametli ve yufka yürekli bir karakter olduğu görülür. Dedesinin anlattığı seferberlik hikâyelerini dinlerken oldukça hüzünlenir, duygulanan dedesine teselli vermeye çalışır. “Dedesinin titreyen sesi ve dolan gözleri Tuna’yı hüzünlendirir, ona güç vereceğini sanarak koluna yaslanır, bir eliyle dedesinin kolunu okşardı" ${ }^{[118]}$ cümlelerinden Tuna’nın yufka yürekli bir çocuk olduğu anlaşılır. Annesi ve babası arasında yaşanan kırgınlıklarda her ikisine de ayrı ayrı merhamet duyar. "Hangisine acıyacağımı şaşırırdım. Annemin tutkulu hayalleri ve düş kırıklığ 1 dolu inlemeleri arasından kaçıp, terzi dükkânına sığınan babama mı, yoksa ondan kapasitesi dışında şeyler bekleyen anneme mi" ${ }^{[119]}$ ifadeleri Tuna'nın merhamet dolu, yufka yürekli bir erkek olduğunun göstergesidir. Ada’nın sigara içmesi bile ona bir şey olacak endişesi ile Tuna’yı üzer. "Şimdi bile, Ada ne zaman sigara içse içimi bir üzüntü kaplar, kanser olacak diye içim titrer" ${ }^{[120]}$ sözleri Ada’ya duyduğu merhamete örnektir. Ayrıca Aras’ın Ada’yı üzdüğü vakitlerde yine Ada için üzülecek kadar yufka yüreklidir. "Gözlerinin kumrallığında oynaşan hüzünlü ela 1şılar içimi burkuyordu. Ada’yı üzdügü vakitler ağabeyime feci bozuluyordum"[121] cümleleri de Tuna’nın yufka yürekli bir kişiliğinin olduğunu göstermektedir. Tuna Meriç’le yaptığı evliliği dahi

\footnotetext{
116 Zehra Yaşın Dökmen, Toplumsal Cinsiyet Sosyal Psikolojik Açılamalar, s. 220.

117 Buket Uzuner, Kumral Ada Mavi Tuna, s. 394.

118 Buket Uzuner, Kumral Ada Mavi Tuna, s. 51.

119 Buket Uzuner, Kumral Ada Mavi Tuna, s. 208.

120 Buket Uzuner, Kumral Ada Mavi Tuna, s. 215.

121 Buket Uzuner, Kumral Ada Mavi Tuna, s. 221.
} 
ona duyduğu merhametten dolayı yapar. Kendi mutluluğunu hiçe sayarak, Meriç’i mutlu etmek için böyle bir evliliğe karar verir. "Hiç değilse beni seven birini mutlu edeyim diye Meriç'le evlendim ve onunla yaşıyorum. Hem insanları hoşnut etmekten zevk alan doğuştan 'iyi' olmak zorunda birisiyim ben..." ${ }^{[122]}$ sözlerinden bu çıkarımı yapmak mümkündür. Yufka yürekli ve merhametli olmak kadınsı özellikler arasında yer alan özelliklerdir. ${ }^{[123]}$ Tuna’nın bu özelliklerinin kadınsı sayılan özellikler ile uyumlu olan bir karakter olarak çizildiği görülür.

Tuna’nın bir başka yönü de incinmiş duyguları tamir etmeye istekli olması ve gönül almayı bilen bir erkek olmasıdır. Bunu romanda yer alan "Oysa ben bilirdim. Ada’yı yatıştırmayı, gönlünü almayı çok iyi bilirdim. Yalnızca Ada’yı değil, başta annem olmak üzere sevdiğim ve beni seven kadınların gönüllerini almayı hep başarmışımdır”"[124] cümlelerinden anlamak mümkündür. Tuna gönül almanın kendisi için çok basit bir iş olduğunu söyler. Ağabeyi Aras ise bu konuda çok beceriksizdir. Tuna’nın ağabeyi ile tamamen zıt karakterler olduğunu Tuna’nın aşağıdaki ifadelerinden anlamak mümkündür:

Halbuki okulun karate ve satranç takımlarında birinci olan, fizikte dahi olduğu söylenen, kendi başına bir yabancı dili Ada’yla yarışacak kadar söken, herkesin gözbebeği yakışıklı ağabeyim çok sevdiği Ada’nın gönlünü almayı bilmiyordu... O kadar başarılı ve güçlü olan Aras, benim için çocuk oyuncağı olan şeyi beceremiyordu. ${ }^{[125]}$

Aras’ın erkeksi özelliklere sahip bir erkek olarak, kadınsı rollerden sayılan gönül almaya istekli olmak özelliğini ${ }^{[126]}$ taşımadığg görülürken, Tuna için bu çocuk oyuncağı kadar basit bir iştir. Bu özelliği bakımından da Tuna kadınsı bir özellik olan 'incinmiş duyguları tamir etmeye istekli olmak' özelliğini taşımaktadır.

Evde ev işleri ile meşgul olmak, temizlik yapmak, yemek yapmak, bulaşık yıkamak gibi işler kadınla özdeşleşen işlerdir. Romanda Tunảnın ev işleri ile de meşgul olan bir erkek olduğu görülür. "Çiçeklerle şımartılmış balkondaki küçük çay masasına iki kişilik kahvaltı hazırladı. Çayı demledi”"[27] cümleleri Tuna’nın normalde kadınlardan beklenen, sabah kalkıp çayı demlemek, kahvaltıyı hazırlamak gibi işleri yaptığ 1 görülür. "Mutfağı temizledikten sonra ince belli çay bardağına açık bir çay koydu, balkona çıktı"[128] ifadeleri Tuna’nın, mutfak temizliği yapmak gibi

Buket Uzuner, Kumral Ada Mavi Tuna, s. 322.

Celaleddin Vatandaş, "Toplumsal Cinsiyet ve Cinsiyet Rollerinin Algılanışı”, s. 47.

Buket Uzuner, Kumral Ada Mavi Tuna, s. 222.

Buket Uzuner, Kumral Ada Mavi Tuna, s. 222.

Zehra Yaşın Dökmen, Toplumsal Cinsiyet Sosyal Psikolojik Açılamalar, s. 35.

Buket Uzuner, Kumral Ada Mavi Tuna, s. 10.

Buket Uzuner, Kumral Ada Mavi Tuna, s. 11. 
en belirgin kadınsı rolleri de taşıdığı anlamına gelmektedir.

Toplumsal cinsiyet kalıp yargılarına göre erkeklerin birçoğu futbolla ilgilenir. Spor olarak pek çok erkeğin futbolu tercih ettiği görülür. Bir erkeğin futbol oynaması, fanatik olarak bir takım tutması normal karşılanır. ${ }^{[129]}$ Erkeksi özellikler arasında sayabileceğimiz futbolla ilgilenmek, fanatik olarak takım tutmak gibi özelliklerin Tuna’da bulunmadığı görülür. “Tutmuyorum be Sefer. Ben futbolla çok ilgilenmezdim, bilirsin. Bunlar Aras'ın konuları..."[130] cümlelerinden Tuna’nın bu anlamda da erkeksi özellik taşımadığı fark edilir.

Tuna’nın kız erkek ayrımcılığına karşı olduğu da görülür. "Evladın kızı erkeği olur mu Sefer"[131] sözlerini yaşadığ bunalımda, zihninde oğulları ile övündüğünü düşündügü arkadaşı Sefer’e söyler. Bir başka yerde "Benim umurumda değildi ve hiç de olmadı. Cinsiyetler arası farkın, saç, göz renkleri gibi ve kadar önemsiz olduğunu düşünmüşümdür hep... Kadın ya da erkek olmaktan daha fazla önemsediğim değerler vardır benim dünyamda" ${ }^{[132]}$ cümlelerini kullanan Tuna’nın ifadelerinden, cinsiyetçi bir yaklaşıma değil, eşitlikçi bir yaklaşıma sahip olduğu görülmektedir.

Yukarıdaki örnekler Kumral Ada Mavi Tuna adlı romanın başkişisi olan Tuna’nın hassas, duygusal, naif, duyarlı, merhametli, yufka yürekli, içe kapanık, özgüveni olmayan, çekingen ve utangaç bir karakter olduğunu gösterir. Bunların yanı sıra Tuna’nın zayıf ve çaresiz, şiddetten ve saldırganlıktan hoşlanmayan, kolay ağlayan bir erkek olduğu da söylenebilir. Ayrıca incinmiş duyguları tamir etmeye istekli, gönül almayı bilen bir karakter olduğu görülür. Bu özelliklerin tümünün kadınsı özellikler olduğu göz önüne alınarak, Tuna’nın da kadınsı özellikler taşıyan bir karakter olduğu yorumu yapılabilir. Tuna’nın ilgi alanın edebiyat olması ile moda tasarımında becerisinin olması, ev işlerine yatkın olması da kadınsı özelliklerle uyumludur. Bunlarla birlikte Tuna’nın, cinsiyet ayrımcılığına karşı olan, kadının erkekten daha üst bir statüde bulunmasından rahatsızlık duymayan ve bunu destekleyen bir erkek olduğu görülür.

\section{SONUÇ}

Bu çalışmada Buket Uzuner'in Kumral Ada Mavi Tuna adlı eserinde yer alan ana karakterler, toplumsal cinsiyet kalıp yargılarına göre kadınsılık ve erkeksilik özellikleri bakımından incelenmiştir. İncelememizde kitaba ismini veren Tuna ve

129 Ahmet Talimciler, “Futbol Taraftarlığındaki Erkeklik İmgesi:(Bucaspor-Göztepe ve Karşıyaka taraftarları Üzerine Bir İnceleme)", Journal Of Social Scienses and Humanities, 1/1, 2017, s. 28.

130 Buket Uzuner, Kumral Ada Mavi Tuna, s. 91.

131 Buket Uzuner, Kumral Ada Mavi Tuna, s. 98.

132 Buket Uzuner, Kumral Ada Mavi Tuna, s. 107. 
Ada karakteri ile Aras karakteri ele alınmıştır. Ada, Aras ve Tuna’nın toplumsal cinsiyet kalıp yargılarına göre kadınsılık ve erkeksilik özellikleri olarak kabul edilen özellikler ile ne derece uyumlu karakterler olup olmadıkları ortaya konmuştur.

Buna göre Ada karakterinin hem kadınsılık hem de erkeksilik özellikleri taşıd1ğ1 görülmüştür. Kendine güvenen, lider, kararlı, başarılı, hırslı ve cesur özellikleriyle erkeksi; şefkatli, merhametli, güzel, çekici, dişi ve seksi özellikleriyle ise kadınsı özelliklere sahip olduğu ifade edilmiştir. Ada’nın kadın haklarını savunan, kadının ikinci planda olmasını kabul etmeyen bir karakter olarak feminist bakış açısına sahip olduğu ortaya konulmuştur.

Aras adlı karakterin, neredeyse bütün özellikleriyle erkeksi rollerle uyumlu olduğu görülmüştür. Cesur, başarılı, hırslı, lider, zeki, atak, kendine güvenen, sportif, ciddi bir karakter olarak erkeksi özellikleri yansıtan bir karakter olduğu ifade edilmiştir.

Tuna karakteri ise özellikleri bakımından kadınsı olarak kabul edilen, naif, duygusal, duyarlı, hassas, yufka yürekli, merhametli, utangaç, saldırganlıktan ve şiddetten hoşlanmayan, incinmiş duyguları tamir etmeye istekli bir karakter olarak karşımıza çıkmıştır. Dahası, Tuna, ev işleri yapan, daha çok kadınların tercih ettiği varsayılan ilgi alanlarına ilgi duyan ve becerisi olan, kolay ağlayan bir erkektir. Bu noktada Tuna karakterinin romanda, toplumsal cinsiyet kalıp yargılarının tam tersi özelliklere sahip olan bir karakter olarak çizildiği görülmüştür. Eşitlikçi, kadın haklarına saygılı bir karakter olarak karşımıza çıkan Tuna karakterinin, toplumsal cinsiyet ayrımcılığına karşı bir duruşunun olduğu gözlemlenmiştir.

Aras karakterinin, erkekliğini kanıtlamak amacıyla ölümüne sebep olması oldukça dikkat çekicidir. Bu olay, toplumsal cinsiyet kalıp yargılarının, toplumun büyük bir kesimi için hayati öneme sahip değerler olduğunun trajik bir örneğidir. Ataerkil yapının topluma dayattığı bu yargıların, insanın en temel hakkı olan özgürce yaşama hakkını elinden alabilecek güçte dayatmalar olduğu sonucuna ulaşılmıştır.

Tuna karakterinin ise kadınsılık özellikleriyle ele alınması, toplumsal cinsiyet kalıp yargılarının değiştirilmesine yönelik eşitlikçi iletiler vermesi, son derece önem arz etmektedir. Toplumda kadınsı özelliklere sahip olan erkeklerin de görünür kılınmasına dikkat çeken önemli bir örnektir. Toplumsal cinsiyet eşitliğinin sağlanması açısından böyle örneklere ihtiyaç duyulmaktadır. Yazarın Tuna karakteri ile vermiş olduğu iletiler bu anlamda dikkat çekicidir.

Ada karakteri ile erkeksi özelliklere sahip kadınların da olabileceğini kaleme alan yazar, toplumda yer alan bireylerin kendilik algılarını oluştururken kalıp yar- 
gıların aksi yönünde özellikler taşıyabileceklerine dikkat çekmiştir.

Günümüzde halen toplumsal cinsiyet kalıp yargılarının ve toplumsal cinsiyet rollerinin kadınların aleyhine olmaktan çıkamadığı göz önünde bulundurulursa romandaki ana karakterlerin bunun aksi şekilde ele alınmış olması önem arz eder. Özellikle romana ismini veren Tuna ve Ada karakterinin toplumsal cinsiyet kalıp yargılarının tersine özelliklerle sunulması toplumsal cinsiyet eşitliğinin sağlanması yönünde okurlarına olumlu iletiler verir. Kadının ikincil konumda bırakılmasının engellenmesi hususunda topluma katkı sağlayacak bir eser olduğu çıkarımı yapılabilir.

Tüm bunlara dayanarak Uzuner'in Kumral Ada Mavi Tuna eserinin, toplumda var olan kadın erkek eşitsizliğinin giderilebilmesine, bu konuda farkındalık kazanılmasına katkı sağlayabilecek bir eser olduğu sonucuna ulaşılmıştır. Çalışmanın edebiyat, sosyoloji ve özellikle kadın çalışmaları alanlarına katkı sağlaması beklenmektedir.

\section{KAYNAKLAR}

AKDOĞAN, Ramazan ve Gürhan Can, “Utangaçlıkta Cinsiyet Rolü Bir Risk Faktörü mü?”, Istanbul Üniversitesi Kadın Araştırmaları Dergisi, 2019, ss. 1-13.

AltıNDAL, Yonca, "Kadınları Tepeden Tırnağa Boyayan Kadınlar: Güzellik Salonlarında Çalışan Kadınların Iş, Yaşam ve Aile Döngüleri Yaşam ve Aile Döngüleri”, Marmara Üniversitesi Kadın ve Toplumsal Cinsiyet Araştırmaları Dergisi, 1/1, 2017, ss. 61-73.

ATAY, Tayfun, Çin Işi, Japon Işi, İstanbul 2017.

AYDIN, Betül ve Ayşe Nur Kavuncu, "Farklı Sosyo-Ekonomik Düzeylerdeki Lise Öğrencilerinde Cinsiyet Rollerinin Araştırılması", Psikolojik Danışma ve Rehberlik Dergisi, 1/2, 1991, ss. 23-39.

BARUTÇU, Atilla, Türkiye'de Erkeklik Inşasının Bedensel ve Toplumsal Aşamaları, (Yayımlanmamış Yüksek Lisans Tezi) , Ankara Üniversitesi Sosyal Bilimler Enstitüsü Kadın Çalışmaları Anabilim Dalı, Ankara 2013.

BASOW, Susan, Gender Stereotypes and Roles, Brooks/Cole Publishing Company, California 1992.

COLEMAN, James William ve Harold R. Kerbo, Social Problems: A Brief Introduction, Second Edition, Prentice Hall, New Jersey 2003.

CONNELL, William.Raewny, Toplumsal Cinsiyet ve Iktidar Toplum, Kişi ve Cinsel Politika, Cem Soydemir (çev.) , Ayrıntı Yayınevi, İstanbul 2019.

COŞKUN, Anahit ve Resmiye Özdilek, "Toplumsal Cinsiyet Eşitsizliği: Sağlığa Yansıması ve Kadın Sağlı̆ı Hemşiresinin Rolü”, Hemşirelikte Eğitim ve Araştırma Dergisi, 9/3, 2012, ss. 30-39.

ÇAKIR, Özlem, "Türkiye'de Kadının Çalışma Yaşamından Dışlanması", Iktisadi Idari Bilimler Fakültesi Dergisi, 31, 2008, ss. 25-47.

ÇEVLIK, Hale, Güzel Olarak Nitelendirilen Kadın Imgesinin Yorumlanması, (Yayımlanmamış Yüksek Tezi), Süleyman Demirel Üniversitesi Güzel Sanatlar Enstitüsü Resim Anasanat Dalı, Isparta, 2012.

DEMiRBilLEK, Sevda, "Cinsiyet Ayrımcıı̆̆ının Sosyolojik Açıdan İncelenmesi”, Finans, Politik, Ekonomik Yorumlar, 44/511, 2007, ss. 12-27.

DÖKMEN, Zehra Yaşın, "Bem Cinsiyet Rolü Envanteri Kadınsılık ve Erkeksilik Ölçekleri Türkçe Formunun Psikometrik Özellikleri”, Kriz, 44/511, 1999, ss. 27-40.

,Toplumsal Cinsiyet Sosyal Psikolojik Araştırmalar, Remzi Kitabevi, İstanbul 2004.

EREN, Zerrin, Baba Karnım Acıktı Anne Bisikletim Bozuldu, Favori Yayınları, Ankara 2015.

EVRIM, Selmin, Şahsiyet Alanında Psikososyolojik Bir Kavram Olarak Rol Sorununa Giriş, İstanbul Üniversitesi Edebiyat Fakültesi Yayınları, İstanbul 1972. 
KAVUNCU, Ayşe Nur, Bem Cinsiyet Rolü Envanteri'ni Türk Toplumuna Uyarlama Çalışmaları, (Yayımlanmamış Yüksek Lisans Tezi), Hacettepe Üniversitesi Sosyal Bilimler Enstitüsü Eğitim Bilimleri Anabilim Dalı, Ankara 1987.

KILIÇ, Ayşe Nur, vd., "Okul Çağı Çocuklarının Toplumsal Cinsiyet Algıları: Gündelik Yaşam Örnekleriyle Cinsiyetçiliğin Benimsenme Durumuna ve Esneyebilme Olasılı̆̆ına Dair Bir Araştırma”, Sosyoloji Araştırmaları Dergisi, 17/2, 2014, SS. 122-151.

MARSHALL, Gordon, Sosyoloji Sözlüğü, Osman Akınhay-Derya Kömürcü (çev.) , Bilim ve Sanat Yayınları, Ankara 1999.

ÖZDEMiR, Hacı, "Toplumsal Cinsiyet Perspektifinde Erkeklik ve Kadınlık Algısı Bir Alan Araştırması", Akademik Sosyal Araştırmalar, 10, ss. 90-107.

SAKALLIOĞLU, Nuray ve Beril Türkoğlu, "Erkek Olmak ya da Olmamak: Sosyal Psikolojik Açıdan Erkeksilik/Erkeklik Çalışmaları", Türk Psikoloji Yazıları, 22/44, 2019, ss. 52-76.

SANCAR, Serpil, Erkeklik:Imkansız Iktidar, Metis Yayınları, İstanbul 2011.

SULTANA, Abeda, "Ataerkillik ve Kadının Ikincilliği; Kuramsal Bir Analiz", e-Şarkiyat Ilmi Araştırmalar Dergisi, 11/1, Nisan 2019, ss. 417-427.

TALIMCiLER, Ahmet, "Futbol Taraftarlı̆̆ındaki Erkeklik Imgesi: (Bucaspor-Göztepe ve Karşıyaka taraftarları Üzerine Bir Inceleme)", Journal Of Social Scienses and Humanities, 1/1, 2017, s5. 27-57.

TAN, Mine, Ekonomik Yaşamı ve Eğitimi, Türkiye Iş Bankası Yayınları, Ankara 1979.

TDK Sözlük, Ülke Yayınları, İstanbul 1982.

TONGRIMSON, Britta N. ve Christopher Minson, "Sex and Gender: what is the difference?", Journal of Applied Physiology, 99, 2005, 5s. 785-787.

UZUNER, Buket, Kumral Ada Mavi Tuna, Everest Yayınları, Istanbul 2015.

VATANDAŞ, Celaleddin, "Toplumsal Cinsiyet ve Cinsiyet Rollerinin Alglanışı”, Sosyoloji Konferansları, 35, 2011, ss. 29-56.

WATT, Helen, "Gender and Occupational Choice", Handbook of Gender Research in Psychology (Chapter 16), J.C.Chrisler and D.R. McCreary (eds.), Springer Science Business Media, https://www.researchgate.net/ publication/270342201_Watt_HMG_2010_Gender_and_occupational_choice_In_L_C_Chrisler_D_R_ McCreary_Eds_Handbook_of_gender_research_in_Psychology_Ch_16_pp_379-400_New_York_Springer, (27/.10.2020). 
